\title{
Early Cretaceous intra-plate volcanism in the Pieniny Klippen Belt - a case study of the Velykyi Kamenets'/Vilkhivchyk (Ukraine) and the Biała Woda (Poland) sections
}

\author{
Nestor OSZCZYPKO, Dorota SALATA and Michał KROBICKI
}

Oszczypko N., Salata D. and Krobicki M. (2012) - Early Cretaceous intra-plate volcanism in the Pieniny Klippen Belt - a case study of the Velykyi Kamenets'/Vilkhivchyk (Ukraine) and Biała Woda (Poland) sections. Geol. Quart., 56 (4): 629-648, doi: 10.7306/gq.1045

\begin{abstract}
The geological position and geochemistry of the basaltic sill and tuffs occurring within the Berriasian-?Albian pelagic limestones of the Czorsztyn Succession are described. The volcanic rock succession of the Velykyi (= Veliky) Kamenets'/Vilkhivchyk (= Vulkhovchik, Vulhovchik, Olkhivchyk) sites is related to intra-plate submarine volcanism, which took place at the southeastern termination of the Pieniny Klippen Belt. This volcanism was probably associated with the Early Cretaceous opening of the Magura/Fore-Magura basinal system, bounded by the Silesian/Marmarosh and Czorsztyn palaeoridges to the north and south respectively. The alkaline volcanic rocks from the Velykyi Kamenets'/Vilkhivchyk sites are geochemically similar to the basaltic block from Biała Woda (Małe Pieniny Mts., Poland), which is an olistolith a few metres across within the Jarmuta conglomerates (Maastrichtian/Paleocene). This basaltic block was eroded from the frontal part of the Czorsztyn Nappe and was deposited in the uppermost part of the Grajcarek Succession at the southeastern margin of the Magura Basin.
\end{abstract}

Nestor Oszczypko and Dorota Salata, Institute of Geological Sciences, Jagiellonian University, Oleandry 2a, 30-063 Kraków, Poland, e-mails: nestor.oszczypko@uj.edu.pl,dorota.salata@uj.edu.pl; Michat Krobicki, Polish Geological Institute - National Research Institute, Królowej Jadwigi 1, 41-200 Sosnowiec, Poland, AGH University of Science and Technology, Mickiewicza 30, 30-059 Kraków, Poland,e-mail:michal.krobicki@pgi.gov.pl, krobicki@geol.agh.edu.pl (received: April 19, 2012; accepted: July 21, 2012; first published online: November 16, 2012).

Key words: Poland, Ukraine, Pieniny Klippen Belt, Early Cretaceous, geochemistry, alkaline basalts.

\section{INTRODUCTION}

The Pieniny Klippen Belt $(\mathrm{PKB})$ is the main suture zone which separates the Central Carpathians from the Outer Flysch Carpathians. This very narrow zone can be traced for over $600 \mathrm{~km}$ from the Vienna area in the west to the Poiana Botizei (Romania) in the east (Fig. 1A). The PKB successions are built up of Lower/Middle Jurassic to Upper Cretaceous mainly pelagic deposits succeeded by Maastrichtian/Paleocene conglomerates and flysch deposits (Birkenmajer, 1977, 1986). Mesozoic volcanism is poorly expressed in the tectonic evolution of the PKB. One of the few outcrops of Mesozoic basalts is known from the village of Novoselytsia in the TransCarpathian region of Ukraine. These exposures have been researched by us in 2002-2006. These studies helped to establish in detail the geological position of these volcanic rocks and their geochemical characteristics. We also conducted a com- parative study of a basaltic rock at Biała Woda near Szczawnica (PKB, Poland). Preliminary results of this study were presented at the CETEG 08 Meeting in Upohlav-Slovakia (Krobicki et al., 2008). The present paper contains a detailed description of the mineralogical and chemical features of the basaltic body from the Velykyi Kamenets' Quarry, the tuffs from the Velykyi Kamenets' and Vilkhivchyk sections and the basaltic olistolith from the Biała Woda valley. We also discuss the geotectonic setting of these rocks in the light of other studies dealing with geochemistry of Late Mesozoic Carpathian volcanic rocks.

\section{PREVIOUS STUDIES}

Mesozoic mafic volcanic rocks are known from the two localities in the PKB of the Eastern Carpathians (Fig. 1): the 


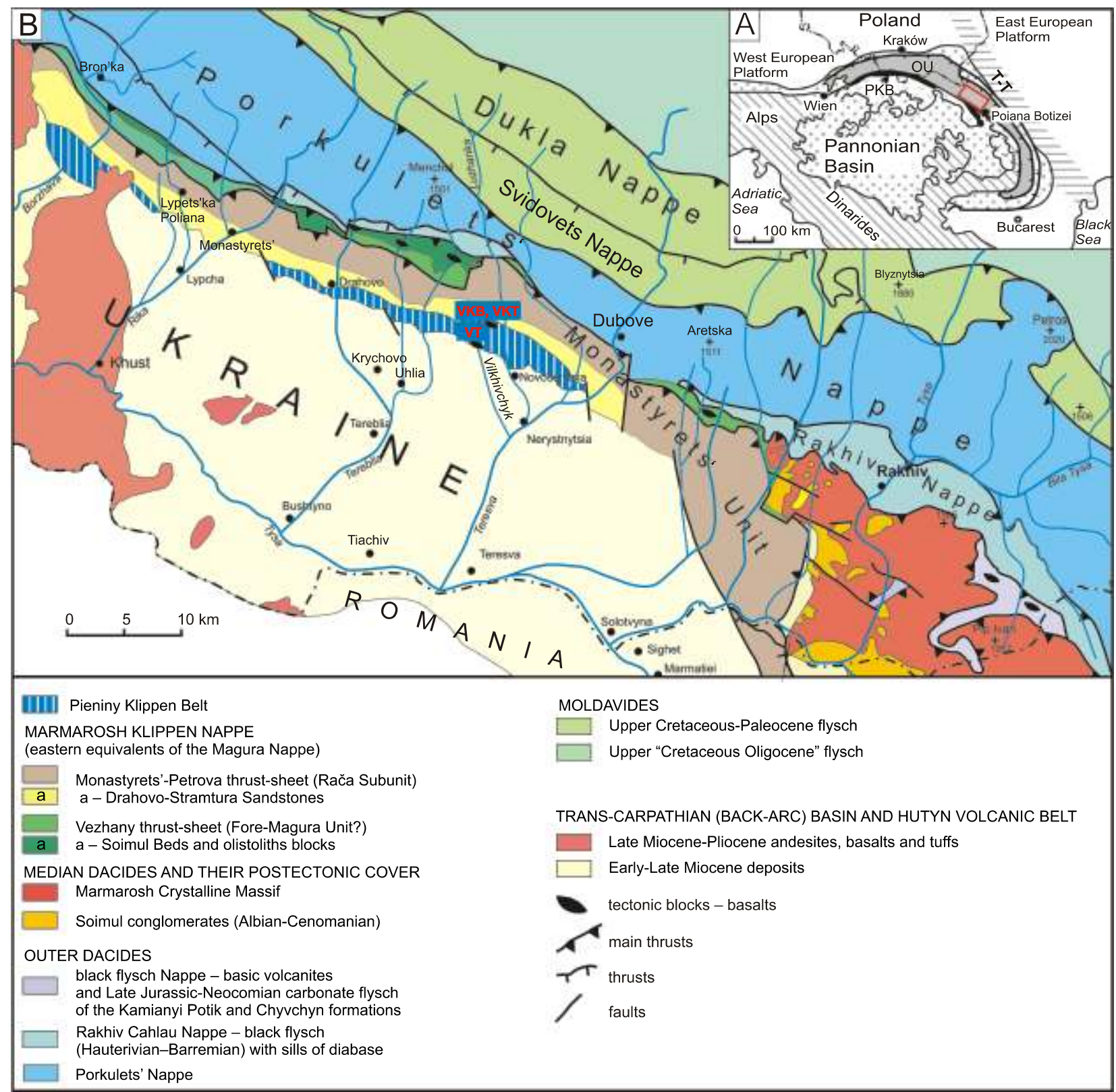

Fig. 1A - location of the area studied in the Alpine-Carpathian-Pannonian system; B - geological sketch-map of the SE part of the Ukrainian Carpathians and adjacent area (based on Oszczypko, 2004)

A: PKB - Pieniny Klippen Belt, OU - Outher Carpathians, T-T - Teisseyre-Tornquist Zone; B: VKB - Velykyi Kamenets' basalt, VKT - Velykyi Kamenets' tuffs, VT - Vilkhivchyk tuffs

Novoselytsia area in Ukraine (Andrusov, 1945; Lomize, 1968) and Poiana Botizei in Romania (Bombi ă and Savu, 1986; Bombi ă and Pop, 1991). Bombi ă and Savu (1986) studied the pyroclastic rocks associated with the Jurassic sequence in the latter locality. Few years later, in the basal portion of this succession, a violet-red pelitic tuff with pumice blocks (Callovian) and Oxfordian detrital-turbiditic limestones with "ophiolitic" fragments of the Petricea Formation were recognized (Bombi ă et al., 1992). In addition, in the PKB the Mesozoic volcanic sequences are known from several localities from the RakhivChyvchyn Ridge, Marmarosh Klippen (Mala and Velyka Uhlia streams), and the frontal part of the Porkulets' Nappe in the Trostianets' Creek and on Petros Mt. (see Krobicki et al., 2005;
Rogoziński and Krobicki, 2006), as well as from the basement of the Trans-Carpathian Neogene depression (Lomize, 1968; Lashkevitsch et al., 1995; Varitchev, 1997; Medvedev and Varitchev, 2000 fide Reháková et al., 2011). The petrography of the volcanic succession has been elaborated in the references listed and there are as follows: Trans-Carpathian Depression basalts, picritic tuffs; PKB - Novoselytsia area: Velykyi Kamenets' - basalts and Vilkhivchyk Stream - trachydolerites; Vezhany Unit (Uhlia and Zabrid' near Drahovo) - diabases, blocks of ultramafic rock (lherzolite); Black Flysch Nappe (Rakhiv-Chyvchyn) - basalts, and the Porkulets' Nappe (Trostianets' and Petros Mt.) - basalts, andesites, trachytes. All these rocks are Early Cretaceous in age. 
The Mesozoic extrusive rocks occurring in the PKB are also known from the vicinity of Vienna (Zoologische Garten Klippen) as well as the Ybbsitz Klippen in Lower Austria (Schnabel, 1992). Recently Spišiak et al. (2008, 2011) described a volcanic body from the Vršatec (Middle Považie region of western Slovakia; Fig. 2A). These volcanic rocks occur within the Cretaceous strata of the Czorsztyn Succession of the PKB and represent mainly a submarine basaltic lava. Moreover, basaltic blocks are known from the Jarmuta (Proč) conglomerate (Maastrichtian-Paleocene) from the PKB (Biała Woda, Poland; see Birkenmajer and Wieser, 1990; Birkenmajer and Lorenz, 2008) and Hanigovce (eastern Slovakia, see Spišiak and Sykora, 2009) (Fig. 2).

\section{GEOLOGICAL SETTING}

\section{TRANS-CARPATHIAN REGION (UKRAINE)}

The Pieniny Klippen Belt runs intermittently from the vicinity of Uzhgorod in the west to the Tereblia-Teresva rivers to the east of the Ukrainian Carpathians (Fig. 1B). The PKB of the Eastern Carpathians is represented by a narrow fragmented belt up to $4-5 \mathrm{~km}$ in width. A larger concentration of klippen is located at Perechyn (NE of Uzhhorod), near Svaliava, Pryborzhavs'ke (= Priborzhavskoye) and Drahovo-Novoselytsia. The PKB of the Eastern Carpathians is trangressively overlain from the south by the Miocene deposits of the TransCarpathian Basin (Fig. 1B). The PKB is initially flatly overthrusted onto the Magura Nappe to the NE of Uzhhorod, and further to the east on the Petrova-Monastyrets' thrust sheet of the Marmarosh Nappe (see Oszczypko, 2004; Oszczypko et al., 2005). The southeastern termination of the PKB is located in the village of Poiana Botizei in Romania. The PKB, bounded to the NE by the Neogene Volcanic Massif and partly by the Botizei Nappe, is flatly overthrusted onto the Wild Flysch Unit there (see Aroldi, 2001; Oszczypko et al., 2005).

\section{VELYKYI KAMENETS' QUARRY}

The last large exposure of the PKB on Ukrainian territory the Velykyi Kamenets' Quarry (GPS 48 10'48.9'N, $\left.3^{\circ} 44^{\prime} 05.4^{\prime \prime} \mathrm{E}\right)$, is located near the village of Novoselytsia (Fig. 1B). The PKB is up to $3 \mathrm{~km}$ wide in this area and is composed of two flatly overthrusted thrust sheets (Kruglov in Ślączka et al., 2006). The southern thrust sheet runs through the Velykyi Kamenets' open quarry, which lies on the top of a hill between the Vilkhivchyk Stream and the Luzhanka River. This quarry is well-known from geological literature (Andrusov, 1945; Slavin, 1966 fide Reháková et al., 2011; Lomize, 1968; Krobicki et al., 2003, 2005; Lewandowski et al., 2005). Recently the integrated statigraphy of the Jurassic to Lower Cretaceous deposits of the Velykyi Kamenets' section has been described by Reháková et al. (2011).

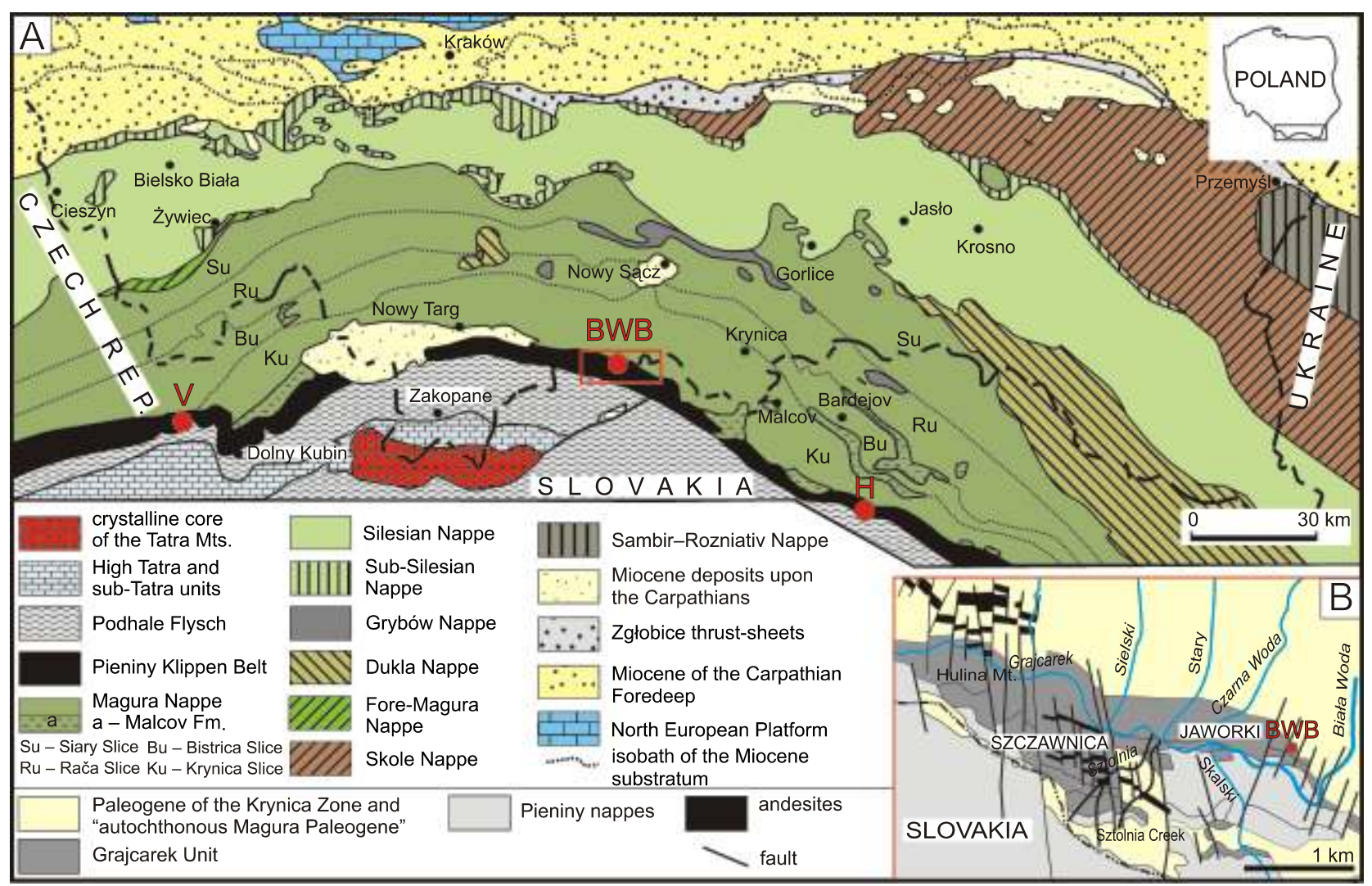

Fig. 2A - structural sketch-map of the Polish Carpathians and the adjacent area (based on Oszczypko, 2004); B - position of the Biała Woda basaltic body in the PKB (based on Birkenmajer, 1979, simplified) 
According to Reháková et al. (2011) this NNE $\left(45^{\circ} / 70^{\circ}\right)$ dipping succession is about 83 metres thick and displays the succession shown in Figure 3. Gresten-type clastic deposits conglomerates and sandstones - up to $28 \mathrm{~m}$ thick occur at the base of the succession. They are followed by black shales with plant fossils and spherosiderites (Aalenian, or Aalenian and Toarcian) at the top (Fig. 3I sequence A). Higher up in the section occurs a carbonate sequence of the Neresnitsa limestones, $41 \mathrm{~m}$ thick. This sequence begins with a Bajocian crinoidal limestone (Fig. 3I sequence B). The upper boundary of the limestone unit is an omission surface coated with ferro-manganese crusts (Krobicki et al., 2003; Lewandowski et al., 2005). The overlying deposits are represented by red nodular Bathonian-Upper Tithonian limestones of ammoni- tico rosso type (Fig. 3I sequence C-E) with intercalations of cherty limestones (Oxfordian/Kimeridgian - Fig. 3I sequence D). The carbonate sequence is ended with thin-bedded, calpionellid-bearing, micritic limestones of Late Tithonian and Early Berriasian age (Figs. 3I sequence $\mathrm{F}$ and 4A; Lewandowski et al., 2005; Reháková et al., 2011). The limestones are penetrated by a thin basaltic intrusion in their uppermost part (Figs. 3I sequence F and 4B, C). It is followed by the $6 \mathrm{~m}$ thick basaltic pillow lava (Figs. 3I sequence $\mathrm{G}$ and 4D). The basalt is overlain by an $80 \mathrm{~cm}$-thick layer of pelagic limestones rich in ammonites, brachiopods and bivalves (Reháková et al., 2011) and following them is $2 \mathrm{~m}$ of dark grey submarine pyroclastic flow deposit - the Velykyi Kamenets' tuffs (Figs. 3I sequence H, I and 4E). Overlying

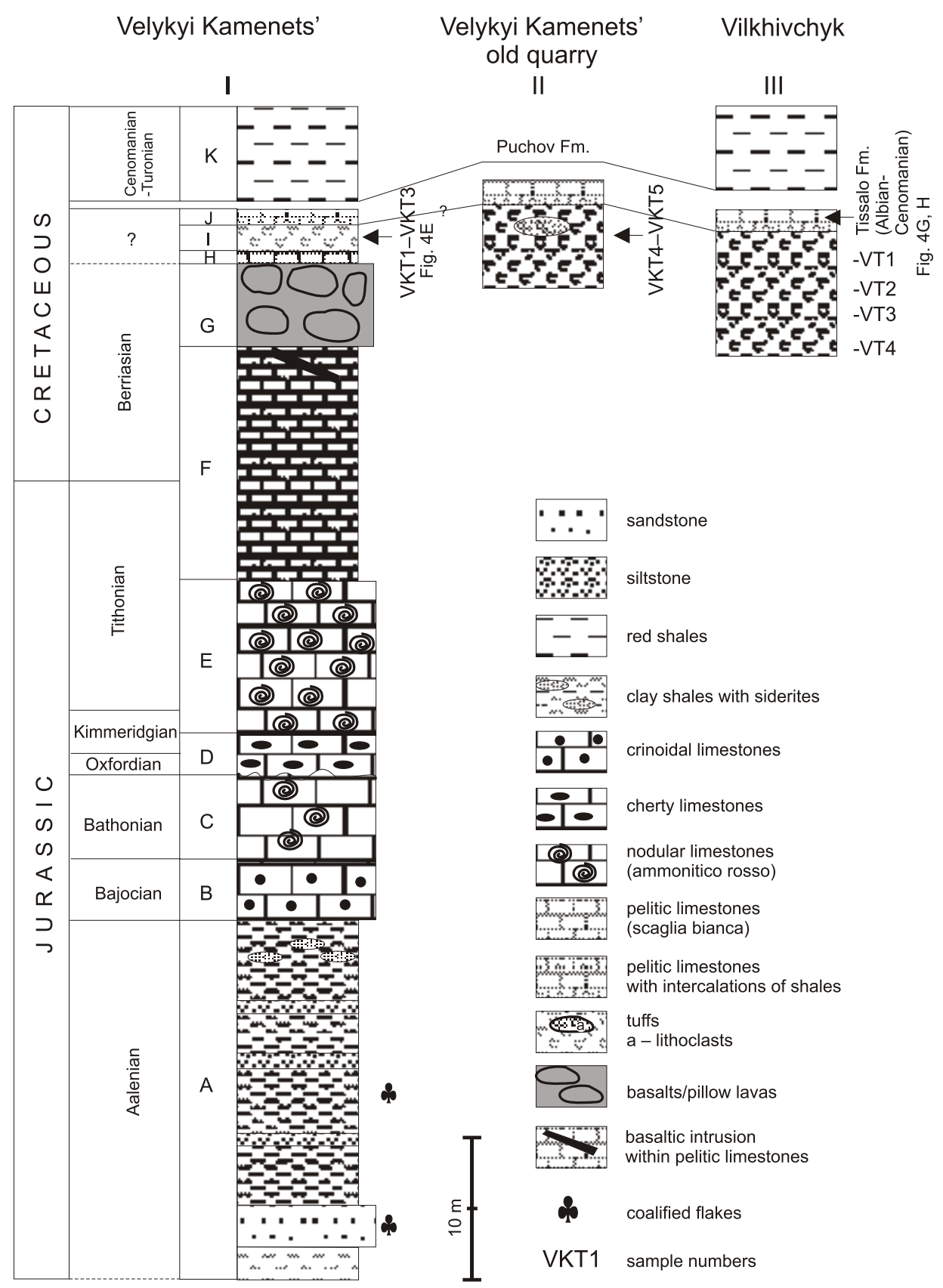

Fig. 3. Geological profiles of the Velykyi Kamenets' section: A-K lithostratigraphic units (based on Reháková et al., 2011 supplemented) and the Vilkhivchyk sections 

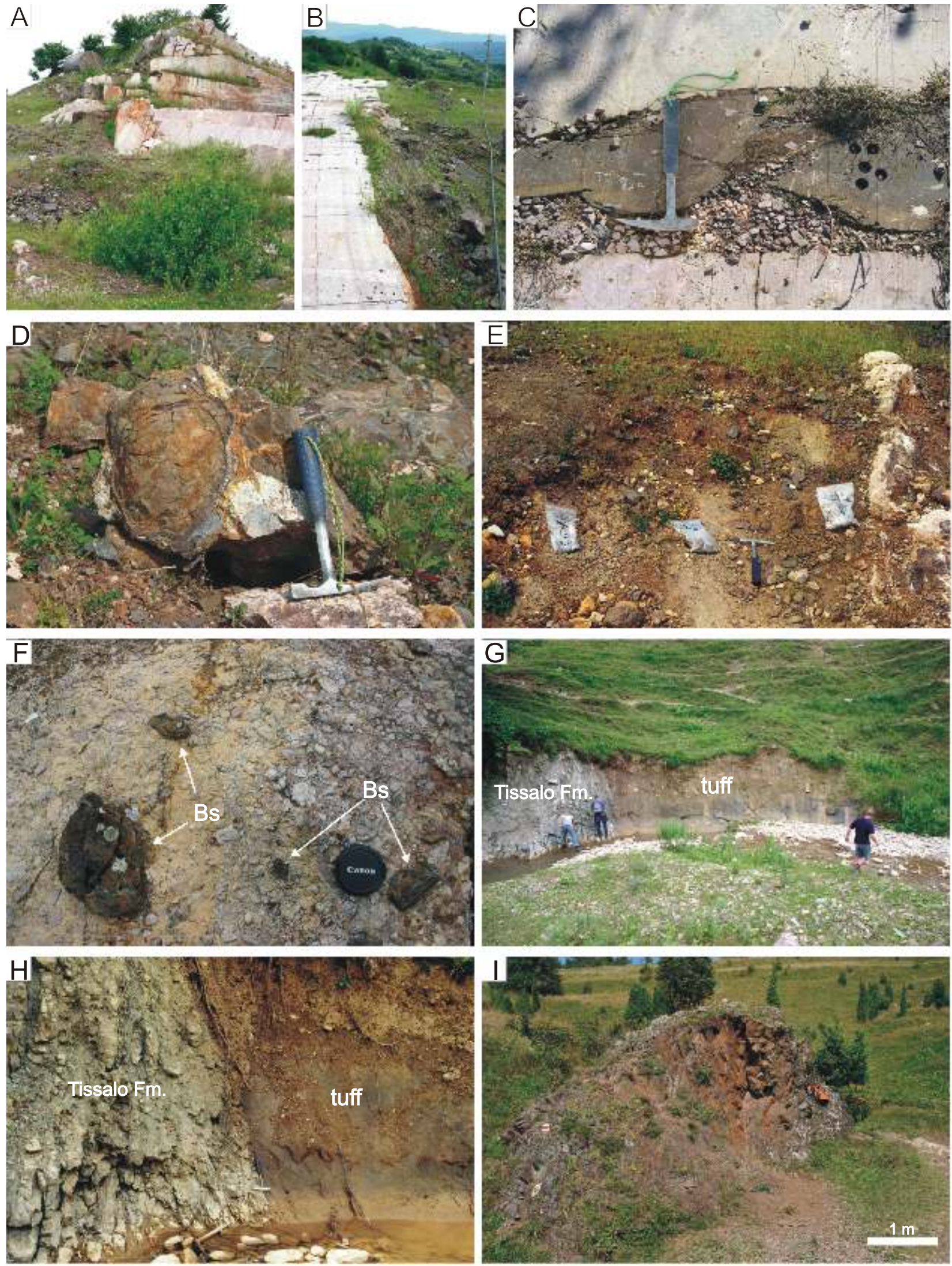

Fig. 4. Photographs of the sections studied (Velykyi Kamenets' and Vilkhivchyk) and the Biała Woda basaltic block

A - Velykyi Kamenets' Quarry - present state; B - contact zone of the basaltic sill with the Berriasian pelagic limestones; $\mathbf{C}$ - uppermost part of the pelagic limestones with the intrusion of the basaltic sill; $\mathbf{D}$ - fragment of pillow lava from the top of the basaltic body; $\mathbf{E}$ - tuffs at the top of the Velykyi Kamenets' section; $\mathbf{F}$ - limestone breccia overlying the tuffs with clasts of basalt (Bs); $\mathbf{G}$ - exposure of the tuffs in the Vilkhivchyk section; $\mathbf{H}$ - contact zone between cherty limestones of the Tissalo Formation and the tuffs in the Vilkhivchyk section; I - Biała Woda basaltic block within the Jarmuta Formation (Maastrichtian-Paleocene) 
the tuffs are breccia limestones (?equivalent of the Walentowa Breccia Member of the Dursztyn Limestone Formation - nomenclature after Birkenmajer, 1977) which represent a synsedimentary limestone breccia with basaltic lithoclasts (Fig. 4F). Dark shales with lenses of yellowish limestone (ca. $20 \mathrm{~cm}$ ), probably belonging to the lower part the Tissalo Formation (?Albian-Cenomanian) are visible at the top of this sequence (Fig. 3I sequence J).

In the Velykyi Kamenets' old quarry, we saw a 6 to $7 \mathrm{~m}$ thick bed of pyroclastic breccia (rich in clasts up to $15 \mathrm{~cm}$ across; Fig. 3II) occurring below the pelitic yellow limestones. This breccia is probably related to the unit labelled as 6-th by Reháková et al. (2011). According to Krobicki et al. (2003), Lewandowski et al. (2005) and Reháková et al. (2011) the Jurassic to Lower Cretaceous deposits of the Kamenets' Succession show similarity to the Czorsztyn Succession (especially the crinoidal limestones) and to the Niedzica Succession (cherty limestones $=$ radiolarites?).

\section{VILKHIVCHYK STREAM SECTION}

The section studied is located in the upper run of the Vilkhivchyk Stream, a right-lateral tributary of the Teresva River (Fig. 1B). This exposure occurs close to the boundary of the PKB and the Trans-Carpathian Neogene Basin. The basal, transgressive portion of the Neogene deposits is represented by dark marine clays (Tereblia Formation), prominent rhyoliticdacitic Lower Badenian Novoselytsia (Dej) tuffs and the Tereshul conglomerates at the base (Ślączka et al., 2006). Around 50 metres north of the base of the Novoselytsia tuff the right bank of the stream there are north-dipping (overturned) beds of cherry-red Puchov-type marls (Upper Cretaceous). The marls are followed by ca. 10 metres of the north-dipping $\left(15^{\circ} / 60^{\circ}\right)$ green marly shales with thin black stripes and thin to medium-bedded pelitic, spotted, cherty limestone intercalations. These rocks probably belong to the Tissalo Formation (Albian-Cenomanian). This formation contacts along a sub-vertical boundary with at least 9 metres of dark grey to green tuffs with cherry-red bands (Figs. 3III and 4G, H). This boundary seems to represent submarine erosive rather than being tectonic in character. The next few tens of metres include thick blocks, which appear more or less in stratigraphic sequence. There are blocks of red nodular limestone of the ammonitico rosso facies, red crinoidal limestones with ammonites and finally blocks of thick-bedded sandstone with ammonites. This sequence of layers is analogous to the lithostratigraphic sequence of the Velykyi Kamenets' section. After a few tens of metres of no exposure, rocks the Upper Cretaceous Puchov-type marls belonging to the more northern thrust sheet are visible.

\section{BIAŁA WODA (MAŁE PIENINY MTS., POLAND)}

A block of basalt a few meters in diameter (Fig. 4I) has long been known from the Biała Woda valley (to the east of the village of Jaworki; Fig. 2; Horwitz and Rabowski, 1929; Kamieński, 1931; Birkenmajer, 1958, 1979). This is an olistolith occurring within conglomerates of the Jarmuta Formation (Maastrichthian-Paleocene) belonging to the Grajcarek Succession (Birkenmajer and Wieser, 1990 and references therein). The block is located directly north of the frontal Czorsztyn Nappe of the PKB (Fig. 2). The radiometric age (K-Ar) of this basalt was determined as $140 \pm 8 \mathrm{Ma}$, an age which corresponds to the boundary between the Jurassic and Cretaceous (Birkenmajer and Wieser, 1990). According to these authors the Biała Woda basalt may have come from the Andrusov Exotic Ridge as an olistolith. More recent radiometric dating by Birkenmajer and Pécskay (2000) for both columnar and platy-jointed varieties of the basalt gave ages of $110 \pm 4.2 \mathrm{Ma}$ and $120.3 \pm 4.5 \mathrm{Ma}$ respectively, equivalent to the Barremian-Albian interval. The basalt has geochemical features of intraplate alkali basalts (Birkenmajer and Lorenc, 2008) and geochemically resembles two olistoliths in the Proč Formation in eastern Slovakia (Spišiak and Sýkora, 2009).

\section{MATERIALS AND METHODS}

Geochemical whole-rock analyses of five samples of tuff from Velykyi Kamenets' (VKT), four samples of tuff from Vilkhivchyk (VT), one sample of basaltic sill from the Velykyi Kamenets' Quarry (VKB) and one sample of the basaltic olistolith from Biała Woda (BWB) were analysed for geochemical proxides of volcanic activity. Major and trace elements were determined by ICP-ES (Inductively Coupled Plasma Emission Spectrometry) and ICP-MS (Inductively Coupled Plasma Mass Spectrometry) respectively at Acme Analytical Laboratories Ltd. in Canada. The chemical composition of the minerals was determined with a wave-dispersion (WDS) electron microprobe using the Cameca $S X-100$ at the Geological Survey of the Slovak Republic in Bratislava and in the Joint-Institute Analytical Complex for Minerals and Synthetic Substances at the Warsaw University. The WDS analyses conditions were: $15 \mathrm{kV}$ accelerating voltage and $20 \mathrm{nA}$ beam current. Synthetic and natural mineral standards were used for analytical calibration. SEM images were made using

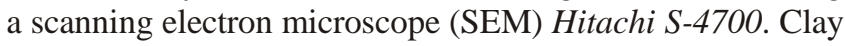
minerals were separated according to the standard method: carbonates were removed with the use of an acetate buffer, organic materials with hydrogen peroxide, while iron oxides were removed following Jackson's (1969; see also Moore and Reynolds, 1997) procedure. The clay mineral fraction was saturated with a $1 \mathrm{M}$ solution of $\mathrm{NaCl}$. The minerals were identified using X-ray powder diffraction in oriented and random powder mounts for the $<0.2 \mathrm{~m}$ fraction. X-ray diffraction analyses were performed with the use of a Philips X'Pert diffractometer with vertical goniometer $P W 3020$ using $\mathrm{CuK} \alpha$ radiation. The mounts were scanned from 2 to $64^{\circ} 2 \theta$. The analyses of the oriented slides were performed in air-dry conditions, after ethylene-glycol vapour treatment and after $1 \mathrm{~h}$ heating at 330 and $550^{\circ} \mathrm{C}$ sequentially. The XRD method was also used for identification of the minerals in the tuffs and basaltic rocks. The content of $\mathrm{CO}_{2}$ in the tuffs was determined according to Scheibler's method, and was used to establish the calcite content in the tuffs. Subsequently the LOI $\left(\mathrm{CO}_{2}\right.$-free) value and the major elements in the tuffs were recalculated to the carbonate-free basis to obtain data comparable with basaltic rocks. 
RESULTS AND DISCUSSION

MINERALOGY

The groundmass of the basalt from the Velykyi Kamenets' Quarry (VKB) is composed predominantly of anorthoclase laths $\left(\mathrm{An}_{6-18} \mathrm{Ab}_{55-60} \mathrm{Or}_{22-37}\right), \mathrm{Fe}-\mathrm{Ti}$ and $\mathrm{Ti}$ oxides and euhedral and subhedral apatite needles (Fig. 5A). The rare microphenocrysts of mafic minerals are totally replaced by chlorite and calcite with spots of Fe and Ti oxides (Fig. 5B). The locally glassy interstices are entirely altered into chlorite with admixtures of calcite (Fig. 5A, B) and serpentine. Small vesicles filled with calcite are typical for this basalt. Fe-Ti oxides display a
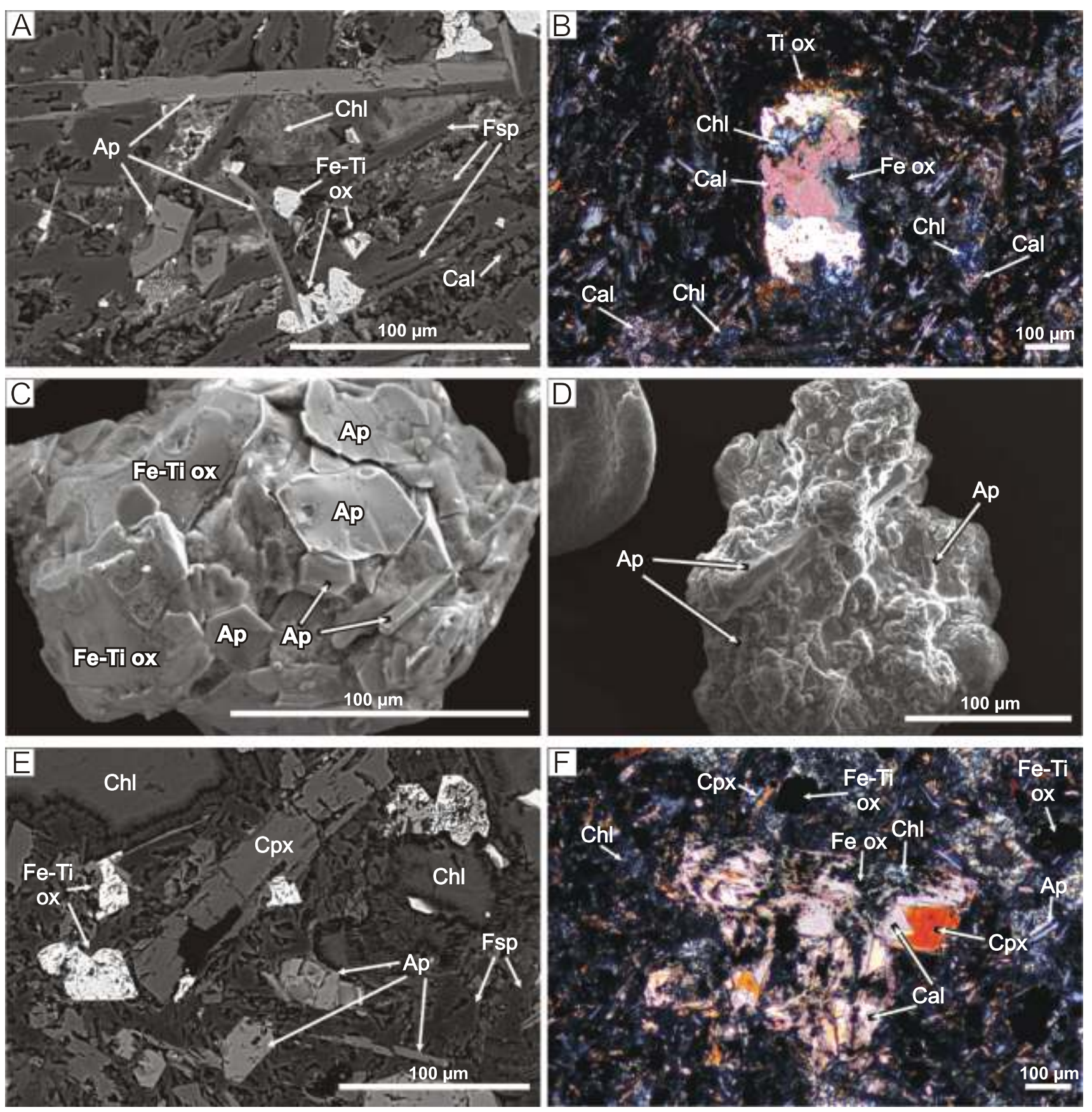

Fig. 5. Microphotographs of the studied rocks

A - SEM BSE image of the groundmass of the basalt from the Velykyi Kamenets' Quarry; B - microphenocryst of a mafic mineral wholly replaced by calcite, chlorite as well as Ti and Fe oxides in the basalt from Velykyi Kamenets' Quarry (XPL - cross-polarized light); $\mathbf{C}$ - euhedral apatite crystals and Fe-Ti oxides in tuff from the Velykyi Kamenets' section in the matrix composed of clay minerals and calcite (SEM); D - euhedral apatite crystals in tuffs from Vilkhivchyk in the matrix composed of clay minerals, calcite and Fe-hydroxides (SEM); $\mathbf{E}$ - SEM BSE image of the groundmass of the basalt from the Biała Woda site; $\mathbf{F}$ - glomerocrysts of clinopyroxene replaced by calcite, chlorite and Fe oxides in the basalt from Biała Woda (XPL); Ap - apatite, $\mathrm{Cal}$ - calcite, Chl - chlorite, Cpx - clinopyroxene, Fe-Ti ox - Fe-Ti oxides; Fe ox - Fe oxides, Fsp - feldspars, Ti ox - Ti oxides 
composition close to ulvöspinel according to the Deer et al. (1992) classification (Fig. 6). They have $\mathrm{Al}_{2} \mathrm{O}_{3}$ content reaching 2.46 wt. $\%, \mathrm{ZnO}$ and $\mathrm{V}_{2} \mathrm{O}_{5}$ up to 0.41 wt.\% and $\mathrm{MnO}$ exceeding 1.90 wt.\% (Table 1). Apatite represents fluorapatite, though rare crystals containing equal amounts of $\mathrm{OH}$ and $\mathrm{F}$ were also noted (Table 2). The apatite analysed contains up to 0.30 wt. $\%$ of $\mathrm{SiO}_{2}, \mathrm{MgO}$ and $\mathrm{FeO}$ reaching 0.38 and 0.53 wt. $\%$ respectively and $\mathrm{SrO}$ up to 0.22 wt.\%. Traces of $\mathrm{La}, \mathrm{Ce}, \mathrm{Mn}$ and $\mathrm{Na}$ were also detected.

The tuffs sampled (VKT, VT) are weakly consolidated and porous. The $>2 \mathrm{~m}$ fraction of the rocks contains the same minerals as were found in the basaltic sill from Velykyi Kamenets' as well as their alteration products. The primary minerals are represented by apatite (Fig. 5C, D), Fe-Ti oxides (Fig. 5C) and feldspars, whereas Fe hydroxides (goethite, lepidocrocite), maghemite and Ti oxides (mainly anatase) belong to alteration products of Fe-Ti oxides while illite is after feldspars (Fig. 7). The Fe-Ti oxides in the tuffs from the Velykyi Kamenets' section have a composition related to ulvöspinel (Fig. 6). The main element concentrations in these spinels are similar to those from the sill, although $\mathrm{Al}_{2} \mathrm{O}_{3}$ (up to 6 wt. \%), $\mathrm{MgO}$ (up to 3 wt. \%) and $\mathrm{ZnO}$ (up to $0.41 \mathrm{wt} . \%$ ) values are slightly higher in the tuffs (Table 1 ). Numerous crystals of euhedral apatite are typical of these tuffs (Fig. 5C, D). They represent the fluorapatite group, although rare

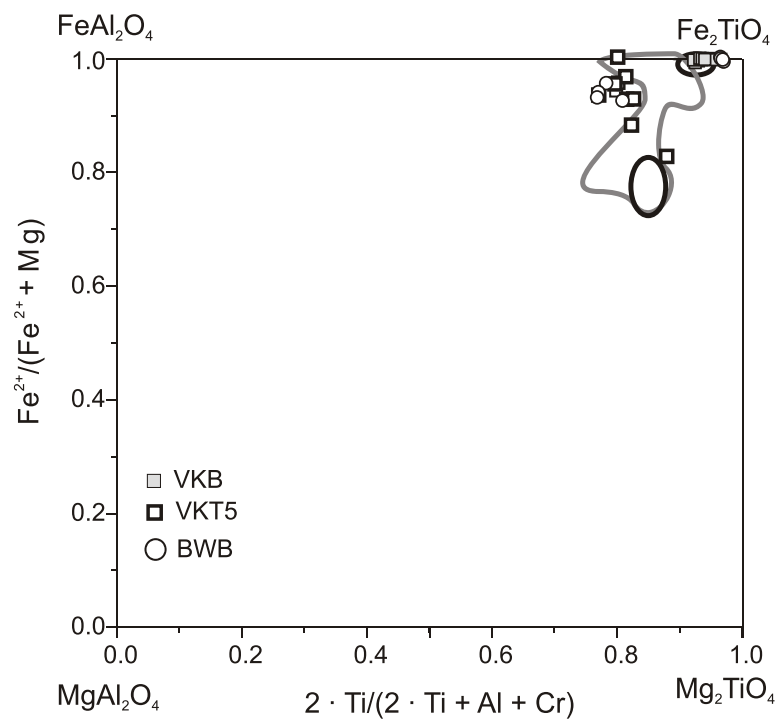

Fig. 6. Composition of the Fe-Ti oxides studied on the classification diagram based on Deer et al. (1992) compared with the oxides from other Carpathian Late Mesozoic alkali basalts

Grey line-field based on Mikuš et al. (2006); black lines-fields based on Spišiak et al. (2011); VKB - basalt from the Velykyi Kamenets' Quarry, VKT - Velykyi Kamenets' tuffs, BWB - Biała Woda basalt

Representative analyses of Fe-Ti oxides occurring in the studied rocks (oxides in wt.\%)

\begin{tabular}{|c|c|c|c|c|c|c|c|c|c|c|c|c|c|c|c|}
\hline \multirow[b]{2}{*}{$\mathrm{V}_{2} \mathrm{O}_{5}$} & \multicolumn{5}{|c|}{ Velykyi Kamenets' basalt (VKB) } & \multicolumn{5}{|c|}{ Velykyi Kamenets' tuffs (VKT5) } & \multicolumn{5}{|c|}{ Biała Woda basalt (BWB) } \\
\hline & 0.26 & 0.41 & 0.36 & 0.31 & 0.24 & 0.29 & 0.35 & 0.41 & 0.37 & 0.30 & 0.34 & 0.41 & 0.37 & 0.25 & 0.41 \\
\hline $\mathrm{SiO}_{2}$ & 0.41 & 0.40 & 0.48 & 0.38 & 0.43 & 0.27 & 0.12 & 0.42 & 0.09 & 0.34 & 0.30 & 0.18 & 0.08 & 0.25 & 0.40 \\
\hline $\mathrm{TiO}_{2}$ & 26.05 & 22.84 & 23.21 & 23.72 & 22.21 & 19.32 & 25.5 & 20.68 & 25.15 & 23.72 & 25.34 & 26.28 & 25.50 & 25.15 & 26.70 \\
\hline $\mathrm{Al}_{2} \mathrm{O}_{3}$ & 1.55 & 2.33 & 2.46 & 2.19 & 1.82 & 6.06 & 4.53 & 5.38 & 4.53 & 1.54 & 1.40 & 1.98 & 1.22 & 1.12 & 2.30 \\
\hline $\mathrm{Cr}_{2} \mathrm{O}_{3}$ & 0.02 & 0.05 & 0.03 & 0.03 & 0.03 & 0.04 & 0.05 & 0.00 & 0.02 & 0.02 & 0.09 & 0.08 & 0.06 & 0.11 & 0.20 \\
\hline $\mathrm{Fe}_{2} \mathrm{O}_{3} *$ & 38.55 & 40.58 & 39.83 & 39.73 & 41.73 & 41.12 & 37.14 & 40.41 & 38.25 & 40.45 & 40.14 & 38.86 & 41.11 & 40.73 & 37.40 \\
\hline $\mathrm{MgO}$ & 0.03 & 0.11 & 0.04 & 0.01 & 0.03 & 0.69 & 2.01 & 0.83 & 2.77 & 0.02 & 0.04 & 0.00 & 0.00 & 0.03 & 0.04 \\
\hline $\mathrm{CaO}$ & 0.17 & 0.12 & 0.08 & 0.14 & 0.11 & 0.06 & 0.12 & 0.15 & 0.11 & 0.10 & 0.22 & 0.15 & 0.13 & 0.10 & 0.22 \\
\hline $\mathrm{MnO}$ & 1.89 & 1.91 & 1.80 & 1.94 & & 0.44 & 0.81 & 0.48 & 0.92 & 1.90 & 1.94 & 1.95 & 1.98 & 1.83 & 1.84 \\
\hline $\mathrm{FeO}$ & 27.93 & 28.04 & 28.10 & 28.17 & 27.87 & 29.64 & 26.97 & 29.17 & 25.91 & 28.04 & 27.89 & 28.46 & 28.42 & 28.35 & 28.52 \\
\hline $\mathrm{ZnO}$ & 0.33 & & 0.41 & & & & & & - & & 0.67 & 0.44 & 0.49 & 0.38 & 0.24 \\
\hline Total & 97.18 & 96.96 & 96.81 & 96.74 & 96.74 & 98.34 & 97.73 & 98.32 & 98.10 & 96.60 & 98.38 & 98.79 & 99.35 & 98.30 & 98.28 \\
\hline \multicolumn{16}{|c|}{ Formula based on 32 oxygen atoms } \\
\hline $\mathrm{V}$ & 0.05 & 0.08 & 0.07 & 0.06 & 0.05 & 0.05 & 0.06 & 0.08 & 0.07 & 0.06 & 0.06 & 0.08 & 0.07 & 0.05 & 0.08 \\
\hline $\mathrm{Si}$ & 0.12 & 0.11 & 0.14 & 0.11 & & 0.08 & 0.03 & 0.12 & 0.02 & 0.10 & 0.09 & 0.05 & 0.02 & 0.07 & 0.11 \\
\hline $\mathrm{Ti}$ & 5.59 & 4.93 & 5.02 & 5.14 & 4.84 & 4.09 & 5.31 & 4.36 & 5.19 & 5.16 & 5.40 & 5.55 & 5.40 & 5.38 & 5.63 \\
\hline $\mathrm{Al}$ & 0.52 & 0.79 & 0.83 & & & 2.01 & & & 1.47 & 0.52 & 0.47 & 0.66 & 0.40 & 0.38 & 0.76 \\
\hline $\mathrm{Cr}$ & 0.01 & 0.01 & 0.01 & 0.01 & 0.01 & 0.01 & 0.01 & 0.00 & 0.00 & 0.01 & 0.02 & 0.02 & 0.01 & 0.03 & 0.05 \\
\hline $\mathrm{Fe}^{3+}$ & 8.27 & 8.77 & 8.62 & 8.61 & 9.10 & 8.70 & 7.73 & 8.52 & 7.91 & 8.81 & 8.56 & 8.21 & 8.71 & 8.72 & 7.90 \\
\hline $\mathrm{Mg}$ & 0.01 & 0.05 & 0.02 & 0.00 & 0.01 & 0.29 & 0.83 & 0.35 & 1.14 & 0.01 & 0.02 & 0.00 & 0.00 & 0.01 & 0.02 \\
\hline $\mathrm{Ca}$ & 0.05 & 0.04 & 0.03 & & & 0.02 & 0.04 & 0.05 & 0.03 & 0.03 & 0.07 & 0.04 & 0.04 & 0.03 & 0.07 \\
\hline $\mathrm{Mn}$ & 0.46 & 0.47 & 0.44 & 0.47 & 0.47 & 0.10 & 0.19 & 0.11 & 0.21 & 0.47 & 0.47 & 0.46 & 0.47 & 0.44 & 0.44 \\
\hline $\mathrm{Fe}^{2+}$ & 6.66 & 6.74 & 6.75 & 6.78 & 6.75 & 6.97 & 6.24 & 6.83 & 5.95 & 6.79 & 6.61 & 6.68 & 6.69 & 6.74 & 6.69 \\
\hline $\mathrm{Zn}$ & 0.07 & 0.04 & 0.09 & 0.03 & 0.08 & 0.09 & 0.02 & 0.08 & - & 0.04 & 0.14 & 0.09 & 0.10 & 0.08 & 0.05 \\
\hline Total & 21.80 & 22.02 & 22.00 & 21.99 & 22.08 & 22.40 & 21.95 & 22.27 & 21.99 & 21.98 & 21.90 & 21.84 & 21.92 & 21.92 & 21.79 \\
\hline
\end{tabular}

\footnotetext{
* - calculated from stoichiometry
} 
Representative analyses of apatites occurring in the rocks studied (oxides in wt.\%)

\begin{tabular}{|c|c|c|c|c|c|c|c|c|c|c|c|c|c|c|c|}
\hline \multirow[b]{2}{*}{$\mathrm{P}_{2} \mathrm{O}_{5}$} & \multicolumn{5}{|c|}{ VKB } & \multicolumn{5}{|c|}{ VKT5 } & \multicolumn{5}{|c|}{ BWB } \\
\hline & 41.34 & 41.00 & 41.50 & 41.72 & 41.15 & 41.00 & 41.90 & 42.07 & 41.43 & 42.31 & 40.73 & 41.87 & 41.58 & 41.06 & 41.02 \\
\hline $\mathrm{SiO}_{2}$ & 0.37 & 0.29 & 0.28 & 0.21 & 0.30 & 0.28 & 0.32 & 0.42 & 0.31 & 0.26 & 0.68 & 0.45 & 0.73 & 0.69 & 0.70 \\
\hline $\mathrm{La}_{2} \mathrm{O}_{3}$ & 0.21 & 0.24 & 0.06 & 0.08 & 0.07 & 0.06 & 0.08 & 0.05 & 0.08 & 0.12 & 0.13 & 0.15 & 0.21 & 0.22 & 0.51 \\
\hline $\mathrm{Ce}_{2} \mathrm{O}_{3}$ & 0.00 & 0.00 & 0.27 & 0.31 & 0.28 & 0.11 & 0.04 & 0.13 & 0.08 & 0.06 & 0.46 & 0.32 & 0.55 & 0.23 & 0.55 \\
\hline $\mathrm{MgO}$ & 0.33 & 0.35 & 0.31 & 0.35 & 0.38 & 0.33 & 0.39 & 0.36 & 0.43 & 0.43 & 0.26 & 0.25 & 0.27 & 0.26 & 0.16 \\
\hline $\mathrm{CaO}$ & 54.46 & 55.13 & 54.66 & 54.62 & 54.70 & 53.64 & 53.81 & 53.87 & 53.75 & 53.89 & 53.27 & 53.43 & 53.48 & 53.20 & 52.48 \\
\hline $\mathrm{MnO}$ & 0.04 & 0.14 & 0.00 & 0.03 & 0.01 & 0.06 & 0.10 & 0.00 & 0.07 & 0.01 & 0.00 & 0.00 & 0.05 & 0.07 & 0.03 \\
\hline $\mathrm{FeO}^{*}$ & 0.53 & 0.40 & 0.52 & 0.36 & 0.39 & 0.60 & 0.79 & 0.50 & 0.50 & 0.52 & 0.56 & 0.39 & 0.55 & 0.70 & 0.50 \\
\hline $\mathrm{SrO}$ & 0.18 & 0.16 & 0.14 & 0.16 & 0.22 & 0.32 & 0.20 & 0.12 & 0.19 & 0.20 & 0.32 & 0.27 & 0.24 & 0.27 & 0.41 \\
\hline $\mathrm{Na}_{2} \mathrm{O}$ & 0.07 & 0.04 & 0.05 & 0.05 & 0.06 & 0.11 & 0.16 & 0.09 & 0.19 & 0.13 & 0.00 & 0.01 & 0.00 & 0.01 & 0.05 \\
\hline $\mathrm{H}_{2} \mathrm{O}$ & 0.45 & 0.64 & 0.52 & 0.51 & 0.87 & 0.91 & 0.72 & 0.80 & 0.67 & 0.76 & 0.57 & 0.51 & 0.51 & 0.38 & 0.28 \\
\hline $\mathrm{F}$ & 2.48 & 2.24 & 2.37 & 2.44 & 1.75 & 1.66 & 2.14 & 1.95 & 2.21 & 2.09 & 2.30 & 2.48 & 2.49 & 2.72 & 2.87 \\
\hline $\mathrm{Cl}$ & 0.60 & 0.30 & 0.55 & 0.46 & 0.29 & 0.27 & 0.23 & 0.26 & 0.23 & 0.20 & 0.35 & 0.36 & 0.35 & 0.35 & 0.43 \\
\hline $\mathrm{O}=\mathrm{F}$ & -1.05 & -0.94 & -1.00 & -1.03 & -0.74 & -0.70 & -0.90 & -0.82 & -0.93 & -0.88 & -0.97 & -1.04 & -1.05 & -1.15 & -1.21 \\
\hline $\mathrm{O}=\mathrm{Cl}$ & -0.14 & -0.07 & -0.12 & -0.10 & -0.07 & -0.06 & -0.05 & -0.06 & -0.05 & -0.05 & -0.08 & -0.08 & -0.08 & -0.08 & -0.10 \\
\hline Total & 99.86 & 99.92 & 100.08 & 100.17 & 99.66 & 98.58 & 99.90 & 99.73 & 99.16 & 100.03 & 98.58 & 99.37 & 99.89 & 98.92 & 98.66 \\
\hline \multicolumn{16}{|c|}{ Formula based on 25 oxygen atoms } \\
\hline $\mathrm{P}$ & 5.911 & 5.866 & 5.919 & 5.932 & 5.894 & 5.919 & 5.953 & 5.963 & 5.933 & 5.982 & 5.903 & 5.989 & 5.937 & 5.919 & 5.945 \\
\hline $\mathrm{Si}$ & 0.062 & 0.049 & 0.047 & 0.036 & 0.051 & 0.049 & 0.054 & 0.070 & 0.052 & 0.043 & 0.116 & 0.076 & 0.123 & 0.118 & 0.119 \\
\hline T-site sum & 5.973 & 5.915 & 5.966 & 5.968 & 5.945 & 5.968 & 6.007 & 6.033 & 5.985 & 6.025 & 6.019 & 6.065 & 6.060 & 6.037 & 6.064 \\
\hline $\mathrm{La}$ & 0.013 & 0.015 & 0.003 & 0.005 & 0.004 & 0.004 & 0.005 & 0.003 & 0.005 & 0.007 & 0.008 & 0.010 & 0.013 & 0.013 & 0.032 \\
\hline $\mathrm{Ce}$ & 0.000 & 0.000 & 0.017 & 0.019 & 0.017 & 0.007 & 0.002 & 0.008 & 0.005 & 0.003 & 0.029 & 0.020 & 0.034 & 0.015 & 0.034 \\
\hline $\mathrm{Mg}$ & 0.083 & 0.089 & 0.077 & 0.086 & 0.096 & 0.083 & 0.097 & 0.089 & 0.109 & 0.107 & 0.066 & 0.062 & 0.068 & 0.066 & 0.040 \\
\hline $\mathrm{Ca}$ & 9.854 & 9.982 & 9.866 & 9.829 & 9.915 & 9.800 & 9.674 & 9.665 & 9.743 & 9.642 & 9.772 & 9.671 & 9.664 & 9.707 & 9.626 \\
\hline $\mathrm{Mn}$ & 0.005 & 0.020 & 0.000 & 0.004 & 0.001 & 0.008 & 0.013 & 0.000 & 0.010 & 0.002 & 0.000 & 0.000 & 0.008 & 0.009 & 0.004 \\
\hline $\mathrm{Fe}^{2+}$ & 0.075 & 0.056 & 0.073 & 0.051 & 0.055 & 0.086 & 0.110 & 0.070 & 0.071 & 0.073 & 0.080 & 0.055 & 0.078 & 0.099 & 0.072 \\
\hline $\mathrm{Sr}$ & 0.018 & 0.016 & 0.013 & 0.016 & 0.021 & 0.031 & 0.019 & 0.012 & 0.019 & 0.019 & 0.032 & 0.027 & 0.024 & 0.027 & 0.040 \\
\hline $\mathrm{Na}$ & 0.022 & 0.014 & 0.016 & 0.017 & 0.020 & 0.037 & 0.051 & 0.029 & 0.062 & 0.042 & 0.001 & 0.003 & 0.000 & 0.003 & 0.018 \\
\hline M-site sum & 10.070 & \begin{tabular}{|l|}
10.192 \\
\end{tabular} & \begin{tabular}{|l|}
10.065 \\
\end{tabular} & \begin{tabular}{|l|}
10.027 \\
\end{tabular} & 10.129 & 10.056 & 9.971 & 9.876 & 10.024 & 9.895 & 9.988 & 9.848 & 9.889 & 9.939 & 9.866 \\
\hline $\mathrm{OH}$ & 0.502 & 0.717 & 0.580 & 0.570 & 0.979 & 1.028 & 0.799 & 0.890 & 0.749 & 0.839 & 0.654 & 0.573 & 0.573 & 0.433 & 0.323 \\
\hline $\mathrm{F}$ & 1.327 & 1.198 & 1.264 & 1.300 & 0.938 & 0.895 & 1.137 & 1.036 & 1.184 & 1.105 & 1.245 & 1.323 & 1.327 & 1.465 & 1.553 \\
\hline $\mathrm{Cl}$ & 0.171 & 0.086 & 0.156 & 0.130 & 0.082 & 0.077 & 0.064 & 0.073 & 0.067 & 0.056 & 0.101 & 0.104 & 0.101 & 0.101 & 0.123 \\
\hline $\mathrm{X}$-site sum & 2.000 & 2.000 & 2.000 & 2.000 & 2.000 & 2.000 & 2.000 & 2.000 & 2.000 & 2.000 & 2.000 & 2.000 & 2.000 & 2.000 & 2.000 \\
\hline
\end{tabular}

* - total Fe calculated as $\mathrm{FeO}$

crystals of hydroxylapatite were also noted (Table 2). The apatite has a composition similar to that from the basaltic sill, with amounts of the main elements being nearly at the same levels (Table 2). Among clay minerals, the $<0.2 \mathrm{~m}$ fraction almost exclusively contains illite/smectite (Fig. 8). Only the sample labelled VT3 includes small amounts of kaolinite and chlorite/smectite(?) (Fig. 8). The estimated (according to Moore and Reynolds, 1997), illite content varies in a broad range from about $70 \%$ (VKT1, VKT5, VT3) to $30 \%$ (VT3). Illite is represented by the $1 \mathrm{Md}$ polytype, identified based on 3.66 and 3.07 reflections in the diffraction patterns of random powder mounts. The high amount of illite indicates advanced diagenetic alterations of the tuffs but simultaneously its variability shows that the processes were non-uniform. The minerals are cemented mainly by calcite with sporadic admixtures of dolomite. The tuffs were deposited in a marine environment and are under- and overlain by limestone beds. Therefore, the content of carbonates, especially calcite, is high but also very irregular and differs between samples. Calcite forms a cement but it is also often con- centrated in spheroidal concretions. Its content, obtained by Scheibler's method, ranges from about $8.5 \%$ in the Velykyi Kamenets' section to about $22 \%$ in the Vilkhivchyk section.

The groundmass of the Biała Woda basalt (BWB) is composed mainly of a fine euhedral or subhedral pyroxene, apatite needles, Fe-Ti oxides and plagioclase laths (Fig. 5E). Ti-rich biotite was also noted. The altered (into chlorite) glass with locally occurring carbonates fill spaces between them (Fig. 5E, F). Phenocrysts occurring in the form of single crystals or glomerocrysts are scarce. They are mostly completely replaced by calcite, chlorite and $\mathrm{Fe}$ and $\mathrm{Ti}$ oxides. The original composition of the phenocrysts cannot be properly determined, though relics of original clinopyroxene phenocrysts are partly preserved locally (Fig. 5F). Sporadically olivine(?) totally altered into a mixture of chlorite and $\mathrm{Fe}$ and $\mathrm{Ti}$ oxides may be found. Ba-rich $\mathrm{K}$-feldspar developed in a few places, replacing mafic phenocrysts. Small, scattered vesicles filled with calcite are typical of the basalt. Plagioclase reveals mainly an oligoclase-andesine composition. The oxides are related to ulvöspinel according to 


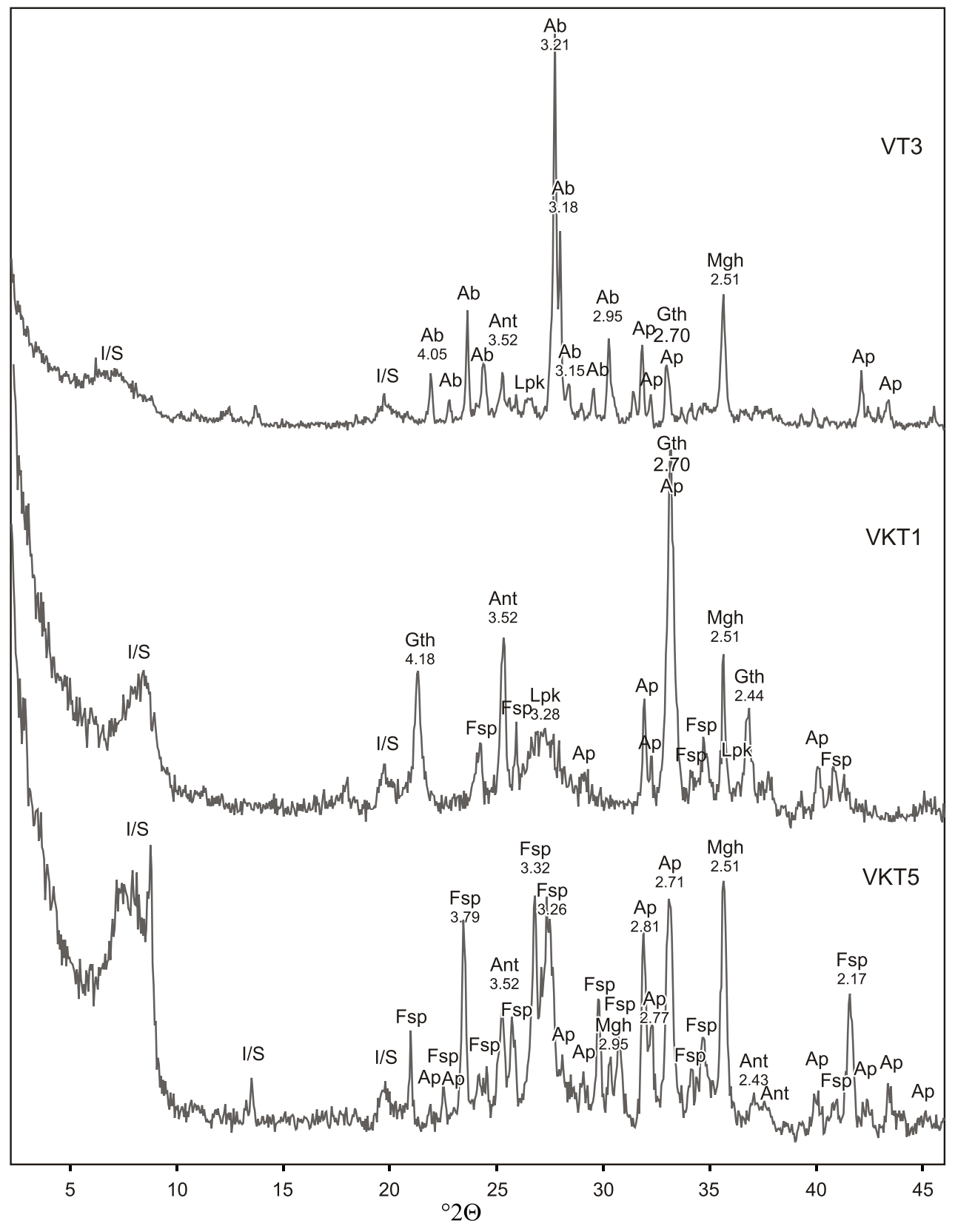

Fig. 7. Representative XRD patterns of the $>2 \mathrm{~m}$ fraction of the tuffs studied

The main measured $\mathrm{d}_{\mathrm{hkl}}$ of minerals occurring in the samples are given; Ab - albite, Ant - anatase, Ap - apatite,

Fsp - alkali feldspar, Gth - goethite, I/S - illite/smectite, Mgh - maghemite, Lpk - lepidocrocite

the Deer et al. (1992) classification (Fig. 6). In terms of chemistry, they resemble oxides from the basalt and tuffs of Velykyi Kamenets'. The $\mathrm{Al}_{2} \mathrm{O}_{3}$ content reaches 2.30 wt. $\%, \mathrm{ZnO}$ and $\mathrm{V}_{2} \mathrm{O}_{5}$ attain 0.67 and 0.41 wt.\% respectively and the $\mathrm{MnO}$ amount exceeds 1.90 wt.\% (Table 1). Apatite displays a fluorapatite composition with oxide amounts very close to those described above in the tuffs and the sill, although the Biała Woda basalt contains slightly higher amounts of $\mathrm{Sr}$ (Table 2). Pyroxene, occurring in the matrix, is surprisingly not altered and is a clinopyroxene rich in $\mathrm{Al}_{2} \mathrm{O}_{3}(3-9 \mathrm{wt} . \%)$ and $\mathrm{TiO}_{2}$ (2-5 wt.\%; Table 3). According to the pyroxene classification of Morimoto et al. (1988) it represents diopside (Table 3).

\section{GEOCHEMISTRY}

The mineralogical and textural features described in the previous section as well as the high LOI level of the rocks studied indicate that they underwent alteration. Therefore, the original amounts of mobile elements, especially the main elements constituting the rock-forming minerals, sensitive to such processes, are certainly changed. Pyroclastic rocks are particularly susceptible to alteration because of their low consolidation and higher porosity, than in basalts. To the group of trace elements regarded as immobile belong the HFS elements (Ti, Sc, Zr, Hf, Nb, Y, Ta) and the REE (e.g., Wedepohl, 1969; Rollinson, 

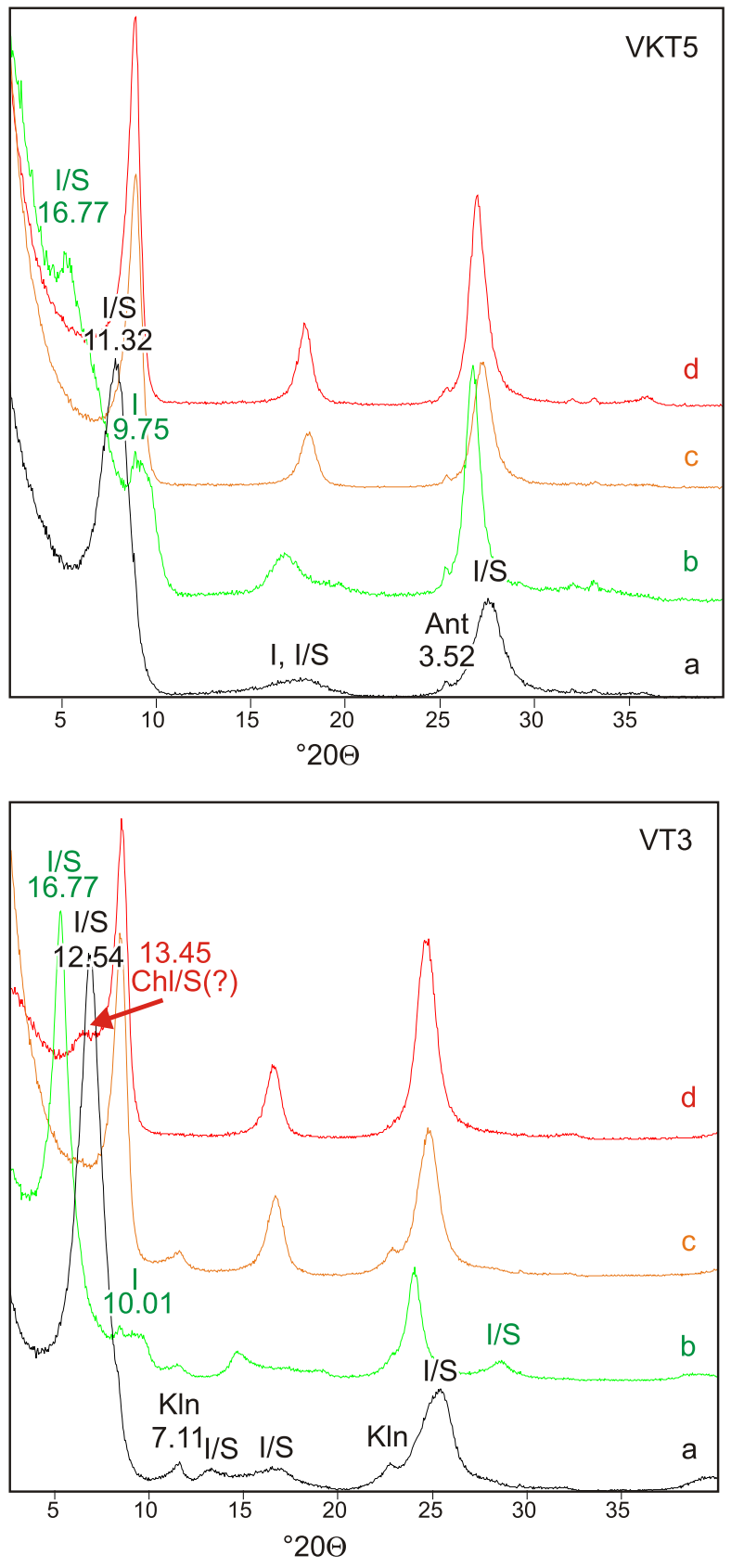

Fig. 8. Representative XRD patterns of the $<0.2 \mathrm{~m}$ fraction of the tuffs studied

$\mathrm{a}$ - air dried, b - ethylene glycol solvated, $\mathrm{c}-$ heated at $330^{\circ} \mathrm{C}$, $\mathrm{d}$ - heated at $550^{\circ} \mathrm{C} ; \mathrm{I} / \mathrm{S}$ - illite/smectite, I - illite, Ant - anatase, $\mathrm{Chl} / \mathrm{S}$ - chlorite/smectite, Kln - kaolinite

1993). However, there are many reports that trace elements are mobilised during alteration processes (e.g., Winchester and Floyd, 1977b; Zielinski, 1982; Summa and Verosub, 1992; van der Weijden and van der Weijden, 1995; Christidis, 1998; Malpas et al., 2001; Büchl and Gier, 2003), though, as was reported by van der Weijden and van der Weijden (1995) the changes in REE values are not considered to be significant. Moreover, the authors referred emphasized that the mobility of elements during alteration processes is extremely complex and controlled by several factors. Additionally, van der Weijden
T a b l e 3

Representative analyses of pyroxenes from the Biała Woda basalt (oxides in wt.\%)

\begin{tabular}{|c|c|c|c|c|c|c|c|}
\hline & \multicolumn{7}{|c|}{ BWB } \\
\hline $\mathrm{SiO}_{2}$ & 42.47 & 45.11 & 49.53 & 46.06 & 46.35 & 46.45 & 46.68 \\
\hline $\mathrm{TiO}_{2}$ & 4.96 & 3.75 & 1.75 & 3.45 & 3.41 & 3.42 & 3.27 \\
\hline $\mathrm{Al}_{2} \mathrm{O}_{3}$ & 8.80 & 7.00 & 3.07 & 7.01 & 6.43 & 6.64 & 6.28 \\
\hline $\mathrm{V}_{2} \mathrm{O}_{3}$ & 0.03 & 0.09 & 0.00 & 0.07 & 0.05 & 0.02 & 0.05 \\
\hline $\mathrm{Cr}_{2} \mathrm{O}_{3}$ & 0.79 & 0.00 & 0.00 & 0.04 & 0.01 & 0.04 & 0.02 \\
\hline $\mathrm{Fe}_{2} \mathrm{O}_{3} *$ & 2.58 & 2.20 & 1.08 & 1.77 & 1.80 & 1.85 & 0.88 \\
\hline $\mathrm{MgO}$ & 10.81 & 11.75 & 13.51 & 11.91 & 12.32 & 12.19 & 11.81 \\
\hline $\mathrm{CaO}$ & 21.06 & 21.89 & 21.80 & 21.62 & 21.46 & 21.90 & 21.44 \\
\hline $\mathrm{MnO}$ & 0.06 & 0.17 & 0.17 & 0.11 & 0.17 & 0.19 & 0.17 \\
\hline $\mathrm{FeO}$ & 6.28 & 5.68 & 6.55 & 6.86 & 6.56 & 5.87 & 7.04 \\
\hline $\mathrm{Na}_{2} \mathrm{O}$ & 0.56 & 0.52 & 0.44 & 0.48 & 0.49 & 0.59 & 0.61 \\
\hline $\mathrm{K}_{2} \mathrm{O}$ & 0.02 & 0.02 & 0.02 & 0.01 & 0.01 & 0.00 & 0.06 \\
\hline Total & 98.42 & 98.18 & 97.91 & 99.38 & 99.04 & 99.16 & 98.31 \\
\hline \multicolumn{8}{|c|}{ Formula based on 6 oxygen atoms } \\
\hline $\mathrm{Si}$ & 1.63 & 1.72 & 1.88 & 1.74 & 1.75 & 1.75 & 1.78 \\
\hline $\mathrm{Al}^{\mathrm{IV}}$ & 0.37 & 0.28 & 0.12 & 0.26 & 0.25 & 0.25 & 0.22 \\
\hline $\mathrm{Al}^{\mathrm{VI}}$ & 0.03 & 0.04 & 0.02 & 0.05 & 0.04 & 0.05 & 0.06 \\
\hline $\mathrm{Ti}$ & 0.14 & 0.11 & 0.05 & 0.10 & 0.10 & 0.10 & 0.09 \\
\hline $\mathrm{V}$ & $<0.01$ & $<0.01$ & $<0.01$ & $<0.01$ & $<0.01$ & $<0.01$ & $<0.01$ \\
\hline $\mathrm{Cr}$ & 0.02 & $<0.01$ & $<0.01$ & $<0.01$ & $<0.01$ & $<0.01$ & $<0.01$ \\
\hline $\mathrm{Fe}^{3+}$ & 0.08 & 0.06 & 0.03 & 0.05 & 0.05 & 0.05 & 0.03 \\
\hline $\mathrm{Mg}$ & 0.62 & 0.67 & 0.77 & 0.67 & 0.69 & 0.69 & 0.67 \\
\hline $\mathrm{Ca}$ & 0.87 & 0.90 & 0.89 & 0.87 & 0.87 & 0.88 & 0.87 \\
\hline $\mathrm{Mn}$ & $<0.01$ & 0.01 & 0.01 & 0.00 & 0.01 & 0.01 & 0.01 \\
\hline $\mathrm{Fe}^{2+}$ & 0.20 & 0.18 & 0.21 & 0.22 & 0.21 & 0.19 & 0.22 \\
\hline $\mathrm{Na}$ & 0.04 & 0.04 & 0.03 & 0.04 & 0.04 & 0.04 & 0.05 \\
\hline $\mathrm{K}$ & $<0.01$ & $<0.01$ & $<0.01$ & $<0.01$ & $<0.01$ & 0.00 & $<0.01$ \\
\hline Total & 4.00 & 4.00 & 4.00 & 4.00 & 4.00 & 4.00 & 4.00 \\
\hline En & 35.05 & 36.88 & 40.33 & 36.96 & 38.01 & 37.78 & 37.26 \\
\hline Fs & 15.83 & 13.78 & 12.86 & 14.84 & 14.40 & 13.46 & 14.13 \\
\hline Wo & 49.12 & 49.34 & 46.81 & 48.21 & 47.59 & 48.76 & 48.61 \\
\hline
\end{tabular}

* - for explanations see Table 1

and van der Weijden (1995) noticed inconsistency in the behaviour of $\mathrm{La}, \mathrm{Ce}, \mathrm{Sm}, \mathrm{Eu}, \mathrm{Tb}$ and $\mathrm{Yb}$ and concluded that conclusions about REE behaviour cannot be generalized based on a single weathering profile.

The high LOI in tuffs (recalculated to a carbonate-free basis; Table 4) suggests advanced alteration of volcanic ash. The LOI value is probably controlled mainly by the water and clay mineral content in the matrix, though primary clay minerals developing from volcanic ash are considered to retain the original REE abundance in the weathered materials (Price et al., 1991 and references therein). Moreover, the negative Ce-anomaly, indicative of deeply weathered materials (Price et al., 1991; Malpas et al., 2001), is not visible in the chondrite-normalized patterns of the tuffs studied. Some differences in the concentrations of elements between the tuffs from Velykyi Kamenets' and those from Vilkhivchyk may be noticed (Table 4) which may be a result of element mobility during diagenesis. Alternatively, the compositional heterogeneity of the tuffs may reflect compositional heterogeneity of the parent magma body. 
T a b l e 4

Whole-rock major and trace element data of representative samples of the Velykyi Kamenets' basalt (VKB), tuffs (VKT and VT), and the Biała Woda basalt (BWB)

\begin{tabular}{|c|c|c|c|c|c|c|c|c|}
\hline \multirow{2}{*}{ Element } & \multirow{2}{*}{ VKB } & \multicolumn{3}{|c|}{ VKT } & \multicolumn{3}{|c|}{ VT } & \multirow{2}{*}{ BWB } \\
\hline & & VKT 1 & VKT 4 & VKT 5 & VT 2 & VT 3 & VT 4 & \\
\hline $\mathrm{SiO}_{2}$ & 43.3 & 40.59 & 39.55 & 42.88 & 41.19 & 42.26 & 41.70 & 42.66 \\
\hline $\mathrm{TiO}_{2}$ & 2.70 & 3.59 & 3.68 & 4.29 & 3.92 & 3.63 & 3.59 & 3.36 \\
\hline $\mathrm{Al}_{2} \mathrm{O}_{3}$ & 14.78 & 15.09 & 14.47 & 17.00 & 14.78 & 15.42 & 14.92 & 13.63 \\
\hline $\mathrm{Fe}_{2} \mathrm{O}_{3} *$ & 13.03 & 15.44 & 11.32 & 16.10 & 13.99 & 13.34 & 15.48 & 12.68 \\
\hline $\mathrm{P}_{2} \mathrm{O}_{5}$ & 1.32 & 2.57 & 2.35 & 2.76 & 3.59 & 1.61 & 2.15 & 0.90 \\
\hline $\mathrm{MgO}$ & 5.72 & 2.91 & 2.86 & 3.67 & 2.39 & 2.94 & 2.98 & 9.85 \\
\hline $\mathrm{CaO}$ & 4.95 & 1.71 & 7.30 & 1.86 & 4.57 & 2.96 & 2.37 & 6.10 \\
\hline $\mathrm{MnO}$ & 0.16 & 0.07 & 0.03 & 0.08 & 0.08 & 0.09 & 0.09 & 0.17 \\
\hline $\mathrm{Na}_{2} \mathrm{O}$ & 2.68 & 0.09 & 0.11 & 1.55 & 0.06 & 0.01 & 0.05 & 1.71 \\
\hline $\mathrm{K}_{2} \mathrm{O}$ & 3.44 & 5.08 & 5.23 & 1.75 & 5.95 & 4.83 & 5.35 & 2.76 \\
\hline LOI & 7.77 & 12.86 & 13.10 & 8.06 & 9.48 & 12.89 & 11.30 & 5.90 \\
\hline TOTAL & 99.9 & 100 & 100 & 100 & 100 & 100 & 100 & 99.75 \\
\hline $\mathrm{CaCO}_{3}$ & - & 19.73 & 20.70 & 8.57 & 10.94 & 22.04 & 22.45 & - \\
\hline $\mathrm{Cr}$ & 20 & 10 & $<10$ & $<10$ & 10 & $<10$ & $<10$ & 290 \\
\hline $\mathrm{Pb}$ & 4.2 & 3.5 & 9.0 & 9.6 & 7.3 & 4.6 & 5.2 & 2.4 \\
\hline $\mathrm{Ni}$ & 12.0 & 8.6 & 60.4 & 14.9 & 7.4 & 4.3 & 4.1 & 87 \\
\hline $\mathrm{Be}$ & 3 & 3 & 1 & 3 & 1 & 2 & 1 & 3 \\
\hline $\mathrm{Co}$ & 28.5 & 24.10 & 36.60 & 57.10 & 27.80 & 16.70 & 18.60 & 40.7 \\
\hline Cs & 0.7 & 1.80 & 3.50 & 3.00 & 4.00 & 4.50 & 4.70 & 0.5 \\
\hline $\mathrm{Ga}$ & 24.9 & 23.30 & 24.30 & 30.20 & 19.20 & 19.70 & 20.70 & 24 \\
\hline Hf & 10.4 & 9.40 & 10.00 & 11.00 & 10.50 & 7.80 & 8.10 & 11.6 \\
\hline $\mathrm{Nb}$ & 103.9 & 97.10 & 110.70 & 120.80 & 113.00 & 80.90 & 86.20 & 110.7 \\
\hline $\mathrm{Rb}$ & 54.2 & 98.10 & 83.20 & 52.40 & 87.10 & 96.00 & 113.30 & 47.7 \\
\hline $\mathrm{Sn}$ & 3 & 3 & 3 & 3 & 3 & 2 & 3 & 3 \\
\hline $\mathrm{Sr}$ & 512.0 & 114.40 & 173.50 & 1192.10 & 203.10 & 112.00 & 118.50 & 789.1 \\
\hline $\mathrm{Ta}$ & 6.2 & 5.50 & 6.70 & 7.10 & 6.50 & 4.80 & 5.00 & 6.2 \\
\hline Th & 7.7 & 7.20 & 7.50 & 7.30 & 8.40 & 5.50 & 6.90 & 10.3 \\
\hline $\mathrm{U}$ & 2.1 & 1.80 & 2.10 & 2.20 & 3.00 & 1.50 & 2.20 & 2.6 \\
\hline $\mathrm{V}$ & 114 & 123 & 118 & 170 & 133 & 114 & 113 & 198 \\
\hline $\mathrm{W}$ & 0.8 & 0.60 & 0.70 & 0.70 & 0.70 & 0.40 & 0.50 & 0.5 \\
\hline $\mathrm{Zr}$ & 499.7 & 386.90 & 434.70 & 471.20 & 421.60 & 318.80 & 335.90 & 456.3 \\
\hline$Y$ & 33.7 & 45.50 & 40.50 & 53.70 & 54.80 & 26.70 & 35.00 & 33.3 \\
\hline $\mathrm{La}$ & 79.3 & 76.30 & 75.20 & 82.00 & 103.80 & 41.10 & 57.80 & 72.2 \\
\hline $\mathrm{Ce}$ & 165.0 & 169.90 & 166.10 & 185.80 & 223.60 & 95.40 & 130.50 & 140.8 \\
\hline $\operatorname{Pr}$ & 18.87 & 19.40 & 18.53 & 21.17 & 25.06 & 10.72 & 17.23 & 17.59 \\
\hline $\mathrm{Nd}$ & 73.5 & 83.90 & 83.30 & 98.00 & 104.80 & 49.20 & 66.00 & 73.1 \\
\hline $\mathrm{Sm}$ & 13.17 & 15.30 & 15.10 & 18.20 & 18.70 & 9.50 & 11.80 & 11.76 \\
\hline $\mathrm{Eu}$ & 3.90 & 5.01 & 4.50 & 5.78 & 5.83 & 3.02 & 3.75 & 3.46 \\
\hline $\mathrm{Gd}$ & 10.07 & 12.72 & 12.12 & 15.88 & 16.01 & 7.97 & 10.32 & 9.52 \\
\hline $\mathrm{Tb}$ & 1.51 & 1.82 & 1.70 & 2.21 & 2.22 & 1.19 & 1.40 & 1.49 \\
\hline Dy & 6.67 & 9.22 & 8.14 & 11.41 & 10.91 & 5.74 & 6.85 & 6.64 \\
\hline Ho & 1.33 & 1.57 & 1.47 & 1.90 & 1.83 & 0.95 & 1.21 & 1.09 \\
\hline Er & 3.31 & 3.90 & 3.48 & 4.53 & 4.45 & 2.38 & 2.82 & 2.78 \\
\hline $\mathrm{Tm}$ & 0.44 & 0.49 & 0.46 & 0.57 & 0.55 & 0.29 & 0.37 & 0.36 \\
\hline $\mathrm{Yb}$ & 2.92 & 3.34 & 2.89 & 3.68 & 3.38 & 1.95 & 2.37 & 2.11 \\
\hline $\mathrm{Lu}$ & 0.41 & 0.38 & 0.36 & 0.47 & 0.43 & 0.25 & 0.33 & 0.29 \\
\hline $\mathrm{Ba}$ & 694 & 51.70 & 297.00 & 562.10 & 223.40 & 91.70 & 98.70 & 760.3 \\
\hline $\mathrm{La}_{\mathrm{N}} / \mathrm{Yb}_{\mathrm{N}} * *$ & 18.45 & 15.52 & 17.68 & 15.14 & 20.86 & 14.32 & 16.57 & 23.25 \\
\hline $\mathrm{La} / \mathrm{Nb}$ & 0.76 & 0.79 & 0.68 & 0.68 & 0.92 & 0.51 & 0.67 & 0.65 \\
\hline $\mathrm{Th} / \mathrm{La}$ & 0.097 & 0.094 & 0.100 & 0.089 & 0.081 & 0.134 & 0.119 & 0.143 \\
\hline $\mathrm{Nb} / \mathrm{Th}$ & 13.49 & 13.49 & 14.76 & 16.55 & 13.45 & 14.71 & 12.49 & 10.75 \\
\hline $\mathrm{Zr} / \mathrm{Nb}$ & 4.81 & 3.98 & 3.93 & 3.90 & 3.73 & 3.94 & 3.90 & 4.12 \\
\hline $\mathrm{Th} / \mathrm{Nb}$ & 0.07 & 0.07 & 0.07 & 0.06 & 0.07 & 0.07 & 0.08 & 0.09 \\
\hline
\end{tabular}

Therefore, considering the above, elements commonly regarded as mobile were, if possible, avoided in the discussion as well in the discrimination diagrams, though this generated constraints in the interpretation. However, the trace elements used for constructing discrimination diagrams and normalized patterns behave mostly coherently, indicating that they behaved conservatively during alteration.

Dilution of the pyroclastic material with terrigenous matter is another problem in consideration of the tuffs. Nevertheless, delivery of clastic material at the time of tuff deposition seems to have been limited since the tuffs were deposited in marine environment characterized by pelagic limestones (hence high calcite content; see Table 4). Marly deposits appear higher, above the tuff horizons (see Fig. 3). Besides, among the clay minerals in the tuffs, mainly illite/smectite with $1 \mathrm{Md}$ illite are present. This suggests that the clay minerals in tuffs are of diagenetic, not detrital, origin. Additionally, the $>2 \mathrm{~m}$ fraction contains the same minerals (apatite, Fe-Ti oxides, feldspars) as the basaltic body and their alteration products (maghemite, Ti oxides, Fe hydroxides; Fig. 7). Moreover, the presence of detrital quartz was not detected.

The chemical composition of the tuffs studied is similar to that of both basalts and is characterized by low $\mathrm{SiO}_{2}$ contents (43 wt.\% in VKB, about 40-43 wt.\% in tuffs, and 43 wt.\% in BWB; which amount consecutively to: $47,45-48$ and $47 \mathrm{wt} \%$ after recalculation to LOI-free basis), amounts of $\mathrm{TiO}_{2}$ exceeding $3 \mathrm{wt}$ \% in almost all cases and $\mathrm{P}_{2} \mathrm{O}_{5}$ (1.61-3.59 wt.\% for tuffs, 1.32 for VKB and 0.9 wt. $\%$ for BWB) (Table 4). The BWB has a higher content of $\mathrm{MgO}$ (over 9 wt.\%) than was measured in the other rocks, perhaps the result of clinopyroxene in the basalt.

$\mathrm{The} \mathrm{Zr} / \mathrm{TiO}_{2}$ and $\mathrm{Nb} / \mathrm{Y}$ ratios indicate that the tuffs studied are alkali basalts in composition, the Biała Woda basalt as basanite/nephelinite, while the basalt from the Velykyi Kamenets' Quarry represents a composition intermediate between those two compositions (Fig. 9). All the rocks studied

* - total $\mathrm{Fe}$ reported as $\mathrm{Fe}_{2} \mathrm{O}_{3}$; ** - chondrite normalized values according to McDonough and Sun (1995) normalization values major elements in [wt.\%] and LOI in tuffs recalculated to carbonate free basis; trace elements in ppm 


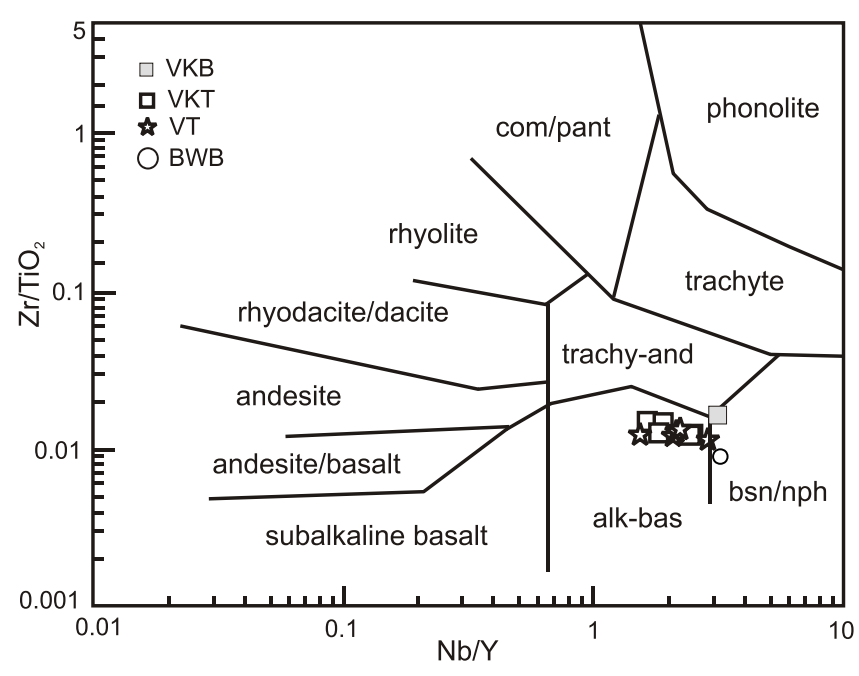

Fig. 9. Classification of the volcanic rocks studied in the diagram based on immobile elements (after Winchester and Floyd, 1977a)

VT - Vilkhivchyk tuffs, VKB - basalt from the Velykyi Kamenets' Quarry, VKT - Velykyi Kamenets' tuffs, BWB - Biała Woda basalt, $\mathrm{bsn} / \mathrm{nph}$ - basanite/nephelinite

correspond to within-plate alkali basalts and/or to within-plate tholeiites (Fig. 10; Wood, 1980; Meschede, 1986).

The rocks studied are enriched in LREE relative to HREE (chondrite-normalized $\mathrm{La}_{\mathrm{N}} / \mathrm{Yb}_{\mathrm{N}}$ values are 15.1-20.9 for tuffs, 18.5 for VKB and 23.3 for BWB; Table 4). Europium anomalies are absent $\left(1.09>\mathrm{Eu} / \mathrm{Eu}^{*}>1\right)$ in all samples studied (Fig. 11A). The chondrite-normalized REE patterns for tuffs as well as for both basalts have steeply-sloping patterns typical of ocean island basalts (OIB) (Fig. 11A). The tectono-magmatic setting is supported by high values of the $\mathrm{Nb} / \mathrm{Th}$ ratio (12.45-16.55 in tuffs, 13.45 for VKB and 10.75 for BWB) and low $\mathrm{La} / \mathrm{Nb}(0.51-0.92$ for tuffs, 0.76 for VKB and 0.65 for BWB) (Table 4) which are compatible with those for basalts of OIB character (Sun and McDonough, 1989; Weaver, 1991; Allègre et al., 1995; and references therein).

The absence of negative $\mathrm{Nb}$ and $\mathrm{Ta}$ anomalies in relation to chondrite (Fig. 12), the $\mathrm{La} / \mathrm{Nb}$ $<0.9$ (Sun and McDonough, 1989) and the $\mathrm{Th} / \mathrm{La}$ lower or close to the 0.12 ( Th/La value of chondrite and primitive mantle; Sun and McDonough, 1989; Table 4) imply that the basaltic melts were not influenced by a crustal component. This is supported by the absence of $\mathrm{Ta}$ and $\mathrm{Nb}$ anomalies in relation to the remaining incompatible elements values in the primordial mantle-normalized patterns (Fig. 13A).

The rocks analysed show a main and trace element composition suggesting that their mantle source had a HIMU (high U/Pb mantle) signature (Fig. 14). Despite the fact that the points in the diagrams constructed according to $\mathrm{K} / \mathrm{Nb}$ vs $\mathrm{Zr} / \mathrm{Nb}$ and $\mathrm{K} / \mathrm{Nb}$ vs $\mathrm{La} / \mathrm{Nb}$ plot into fields partially overlapping with EMII (en- riched mantle type-II) in other diagrams, the distinction is clearly visible (Fig. 14). The $\mathrm{Zr} / \mathrm{Nb}, \mathrm{La} / \mathrm{Nb}, \mathrm{Th} / \mathrm{Nb}$ and $\mathrm{Th} / \mathrm{La}$ values (Table 4) are consistent with those noted for St. Helena and Cook-Austral Islands - the OIB basalts derived from sources having HIMU composition (see Weaver, 1991 and references therein). This is consistent with the hypothesis of this magma source for the rocks studied. The enrichment of LREE relative to HREE, and thus relatively high chondrite-normalized $\mathrm{La} / \mathrm{Yb}$ values in the rocks studied, suggest garnet as a residual phase in the mantle source (Langmuir et al., 1977; Frey et al., 1978). Nevertheless, without more detailed data obtained from fresh rocks, this idea is speculative.

\section{REGIONAL COMPARISON AND CONSIDERATIONS}

The Mesozoic alkaline volcanism of central Europe was related to the opening of the Penninic Rift and was connected with northern and southern marginal parts of the sedimentary basins surrounding the spreading centres. The volcanic bodies are widely dispersed and nowadays placed in several tectonic units of the Alpine-Carpathian-Pannonian realm. There are many reports dealing with the Cretaceous alkaline volcanic rocks from the Central and Outer Carpathians (e.g., Mahmood, 1973; Kudělásková, 1982; Narębski, 1990; Dostal and Owen, 1998; Hovorka et al., 1999 and references therein; Ivan et al., 1999; Spišiak et al., 2011). The volcanic and related rocks predominantly occur in the form of small portions of submarine lava, meagre subsurface bodies such as sills and veins or less frequently as effusive or volcanic rocks. The rocks geochemically belong to a teschenite-picrite association in the Outer Western Carpathians (e.g., Mahmood, 1973; Kudělásková, 1982; Narębski, 1990; Dostal and Owen, 1998) or display compositions of alkali basalts and basanite/nephelinite in the Cen-

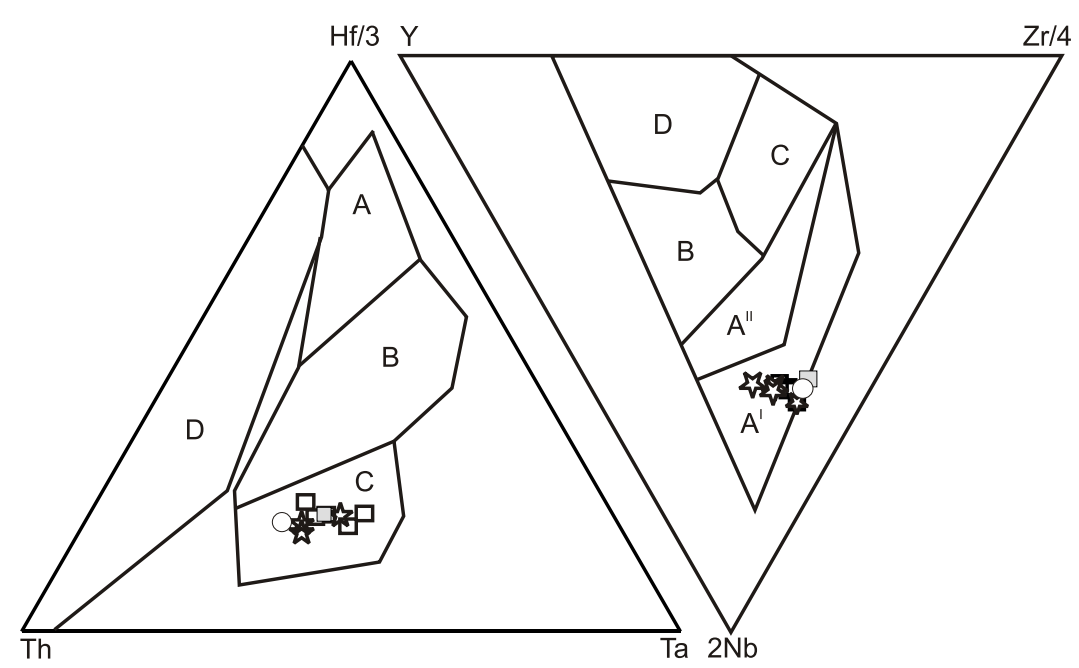

Fig. 10. Discrimination diagrams for the tuffs studied and basalts

Th-Hf/3-Ta (A - N-type MORB basalts, B - E-type MORB basalts, C - within-plate alkali basalts, D - volcanic-arc basalts; Wood, 1980); Zr/4-2Nb-Y (A $\mathrm{A}^{\mathrm{I}}$ - within-plate alkali basalts, $\mathrm{A}^{\mathrm{II}}$ - within-plate alkali basalts and within-plate tholeiites, B - E-type MORB basalts, C within-plate tholeiites and volcanic-arc basalts, D - N-type MORB and volcanic-arc basalts; Meschede, 1986); explanations of symbols in Figure 9 
A

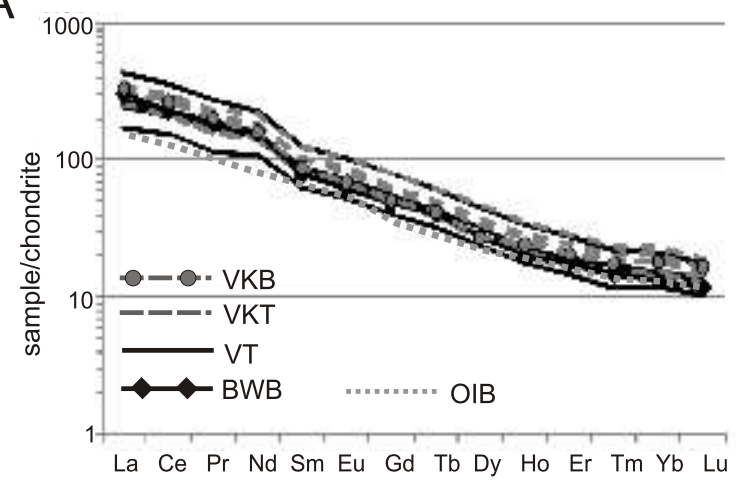

B

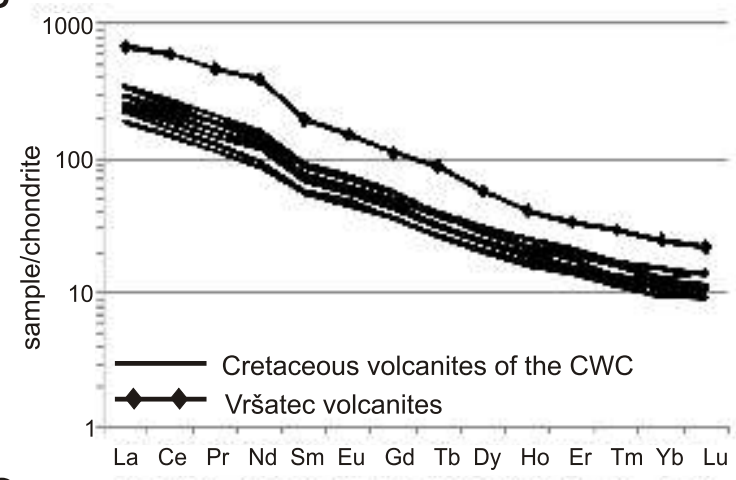

C

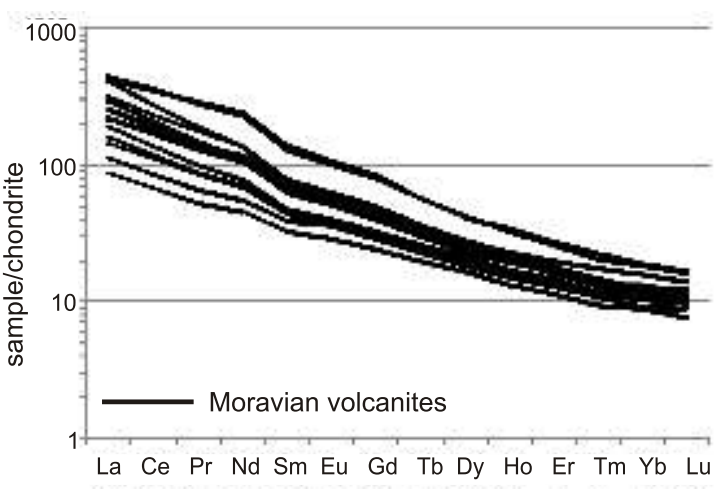

tral Western Carpathians (Hovorka et al., 1999; Ivan et al., 1999). The same alkali type of volcanism represents the recently described melanephelinitic body found in the Púchov segment of the PKB in Slovakia (Vršatec Klippen area; Spišiak et al., 2011).

The Late Mesozoic volcanic rocks are characterized by a typically low content of silica (40-52 wt. $\%$ of $\mathrm{SiO}_{2} \mathrm{LOI}$ free) and increased contents of $\mathrm{TiO}_{2}$ (up to 3.9 wt.\%) and $\mathrm{P}_{2} \mathrm{O}_{5}$ reaching $3 \mathrm{wt} . \%$. The most frequently described minerals are pyroxene (Ti-augite, aegirine, diopside), amphibole, olivine, Ti-biotite, K-feldspar, analcime, plagioclase, apatite and Fe-Ti oxides (Hovorka and Spišiak, 1993; Dostal and Owen, 1998; Hovorka et al., 1999; Ivan et al., 1999; Mikuš et al., 2006; Spišiak et al., 2011). The clinopyroxene, displaying a diopsidic composition, is variably enriched in $\mathrm{TiO}_{2}$ (exceeding 5 wt.\%) and $\mathrm{Al}_{2} \mathrm{O}_{3}$ (up to 10 wt.\%) (Hovorka and Spišiak, 1993; Dostal and Owen, 1998; Hovorka et al., 1999; Mikuš et al., 2006; Spišiak et al., 2011), while the spinels display a composition related to ulvöspinel (see Fig. 6; Mikuš et al., 2006; Spišiak et al., 2011). The rocks are featured by LREE enrichment accompanied by fractionated heavy REE which is reflected in steeply-sloping and smooth chondrite and mantle-normalized patterns respectively (Figs. 11B, C and 13B, C). The geochemical characters of the rocks indicate that they are related to ocean island alkali basalts of intra-plate type with HIMU-derived magma type of possibly garnet-peridotite composition (Dostal

\section{Fig. 11. Chondrite-normalized REE patterns}

A - tuffs studied and basalts; $\mathbf{B}$ - Cretaceous volcanic rocks of the Central Western Carpathians and the Vršatec area (PKB); $\mathbf{C}$ - Moravian volcanic rocks; chondrite normalization factors after McDonough and Sun (1995); data for comparative diagrams compiled from: CWC - Hovorka et al. (1999); Vršatec - Spišiak et al. (2011); Moravian volcanic rocks - Dostal and Owen (1998); average values of ocean island basalts (OIB) after Sun and McDonough (1989); for other explanations see Figure 9

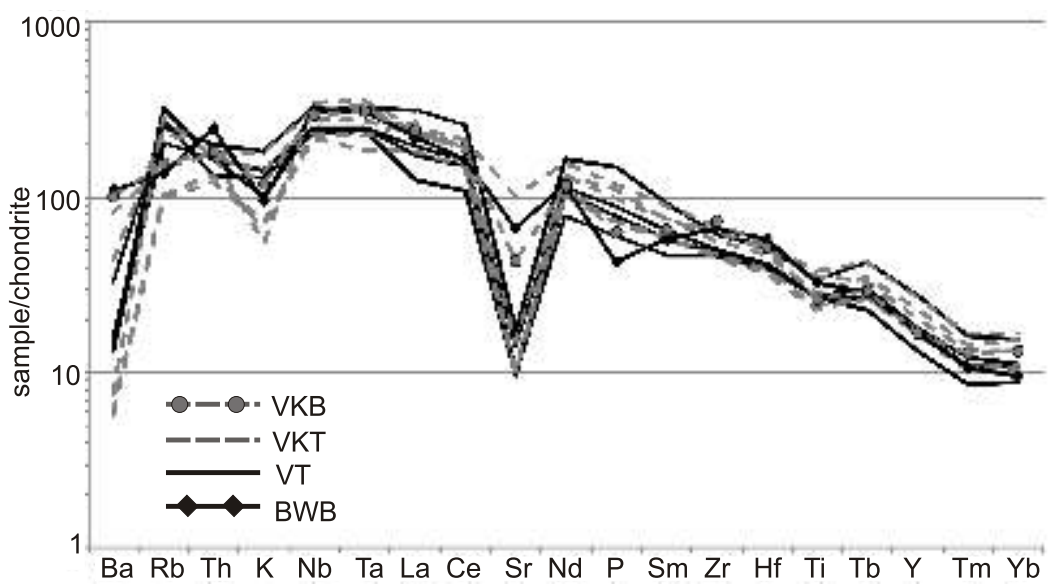

Fig. 12. Chondrite-normalized trace element concentrations in the rocks studied

Normalization according to Thompson (1982); for other explanations see Figure 9 


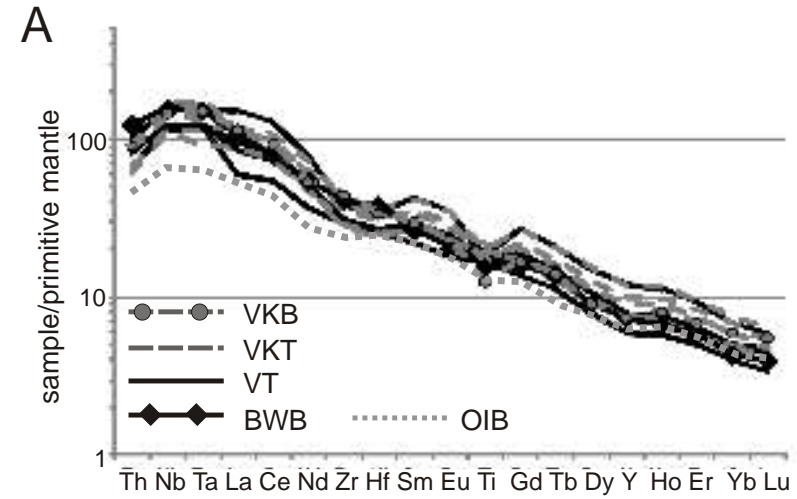

B

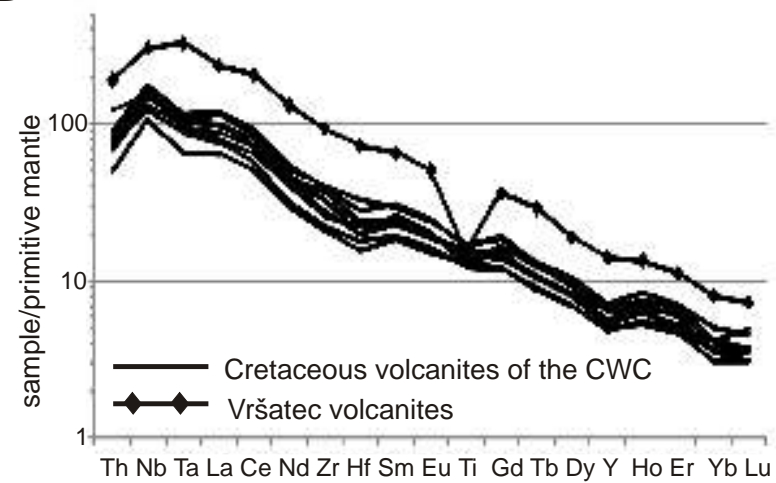

C

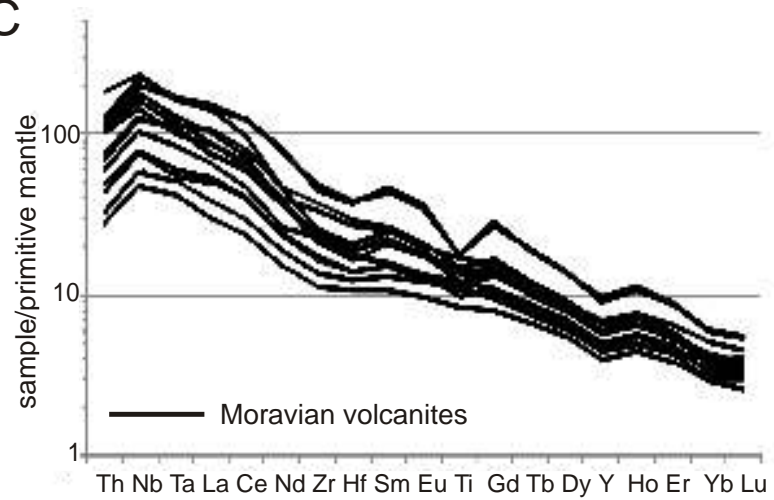

Fig. 13. Primitive mantle-normalized patterns

A - tuffs studied and basalts; B - cretaceous volcanic rocks of the Central Western Carpathians and the Vršatec area (PKB); C - Moravian volcanic rocks; for other explanations see Figure 9

and Owen, 1998; Ivan et al., 1999; Hovorka et al., 1999; Spišiak et al., 2011).

The basaltic sill studied, the tuffs and the Biała Woda basalt seem to represent the same Late Mesozoic volcanic events that took place in the Central Western and Outer Western Carpathians and belong to the same Cretaceous alkaline province. This is supported by:

- mineralogical resemblance and chemical composition of the minerals,

- similar silica, phosphorus and titanium contents,

- REE patterns and proportions of incompatible elements.

The Outer and Central Carpathians' alkaline volcanic rocks as well as those described in this paper show features of ocean island alkali basalts without crustal contamination and have features of HIMU-derived magma type.

Continental and oceanic intraplate alkali basalts may be associated with hot spots, intra-plate stress and extension causing lithospheric thinning and rifting (e.g., Wilson, 1993 and references therein). There are two main models explaining the Late Mesozoic volcanic activity in marginal parts of the Penninic oceanic basins. The alkaline volcanism in rifted areas of Central Europe may be related to "hot mantle fingers" supplied from an asthenospheric reservoir existing under Europe at least since the Early Cretaceous (Harangi et al., 2003), though these authors did not exclude a stretching model. The mantle fingers are believed to represent peripheral branches of hot mantle plumes responsible for opening of the North-Atlantic Basin (e.g., Oyarzun et al., 1997; Wilson, 1997). However, recently Spišiak et al. (2011) proposed an extensional model to explain volcanic activity in the Central Western and Outer Western Carpathians. The model shows that the Carpathian alkaline volcanic bodies, developed along passive continental margins encircling the Penninic rifts, evolved mainly due to mantle upwelling under the stretched lithosphere. According to this model, magma intruded to the surface using deep tensional fractures developed in marginal parts of the peripheral basins.

The Early Cretaceous volcanism at the northern edge of the Pieniny Klippen Belt was probably related to the opening of the Magura Basin, although this theory is still under discussion (Oszczypko and Oszczypko-Clowes, 2009). Traditionally an Early/Middle Jurassic age, coeval with opening of the Ligurian-Penninic Ocean, has been accepted (see Birkenmajer, 1986; Oszczypko, 1992, 1999; Golonka et al., 2000, 2003). According to this concept, the Magura deep-sea basin was separated by the European Shelf and submerged continental(?) Czorsztyn (Oravicum) Ridge from the north and south respectively (Oszczypko, 1999). Alternatively, Plašienka (2003) suggested a Late Jurassic-Early Cretaceous opening of the Magura Basin, accompanied by thermal uplift of the Czorsztyn Ridge, and post-rift thermal subsidence of the Magura Basin, resulting in the uniform deposition of pelagic and hemipelagic shales (?) below the CCD (see Oszczypko and Oszczypko-Clowes, 2009). The same point of view is represented by Schmid et al. (2008) who link opening of the Magura Basin with the Late Jurassic-Early Cretaceous opening of the oceanic Valais-Rhenodanubian (North Penninic) Basin. In the light of this concept, the Czorsztyn Rigde (Oravicum) that occupied a more internal position with respect to the Magura Basin may be regarded as an equivalent of the continental Briançonnais-Hochstegen domain that was flanked to the south by the oceanic Ligurian-Piemont-Vahicum-Krichevo-Szolnok-Sava domain (see Decker, 1990; Schmid et al., 2004, 2008).

During the Late Jurassic to Early Cretaceous, deep-water, condensed deposits of a radiolarite/carbonate sequence occupied the Magura Basin (Fig. 15; see also Oszczypko et al., 2012). Around the Late Jurassic-Early Cretaceous boundary the southern periphery of the Magura and the Czorsztyn sedimentary areas was affected by extensive Neo-Cimmerian gravitational faulting (Birkenmajer, 1986, 1988) and the formation of synsedimentary breccia (Golonka et al., 2003). Because of these tectonic movements, the major part of the Czorsztyn sedimentary area was uplifted and eroded from the Berriasian up to 

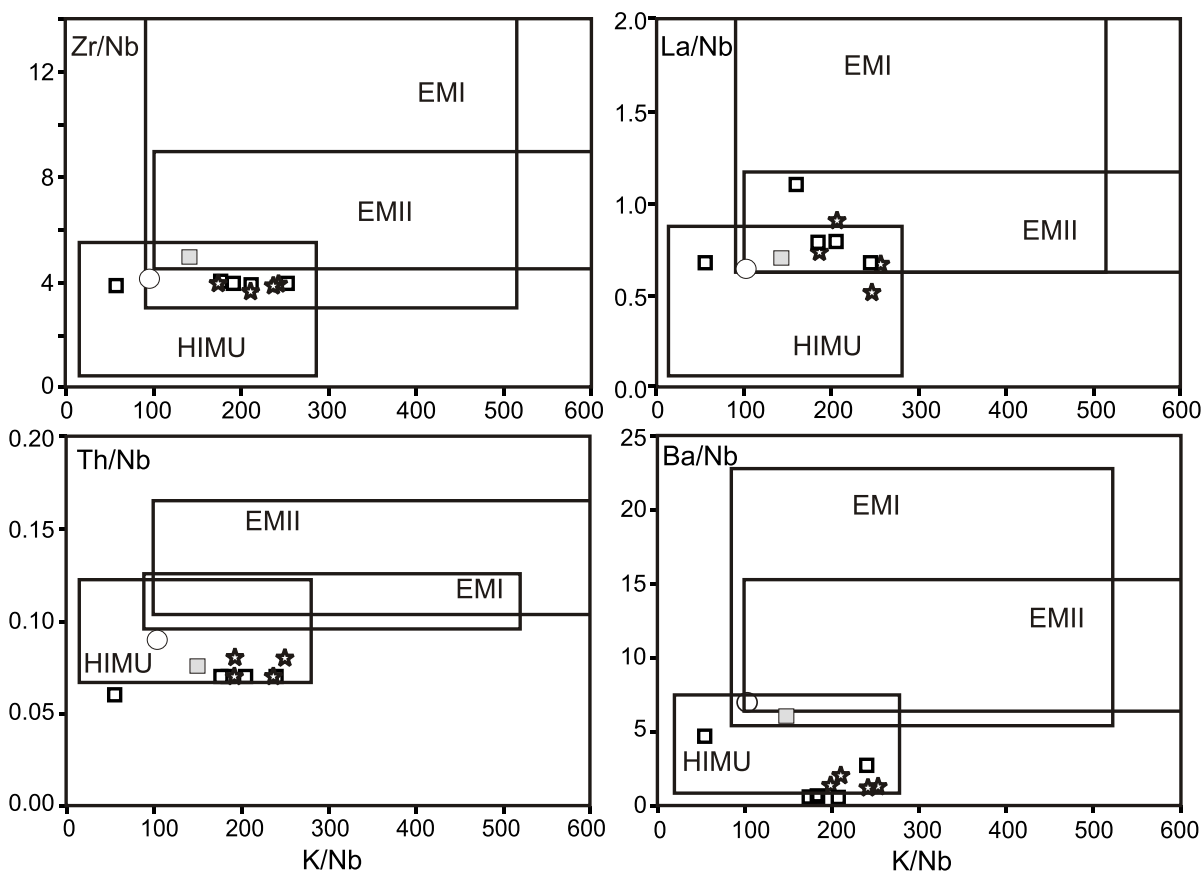

Fig. 14. Geochemical diagrams characterizing mantle reservoirs for the rocks studied

The fields for HIMU, EMI and EMII are based on data compiled by Cook et al. (2005); for explanations see Figure 9

the Aptian/Albian boundary (Birkenmajer, 1986, 1988; Golonka et al., 2003). The Neo-Cimmerian movements might have been manifested by the beginning of sedimentation of flysch deposits of the Szlachtowa Formation in the southern part of the Magura Basin at the Aptian/Albian boundary (Oszczypko et al., 2012). These turbiditic deposits were supplied by clastic material derived from the erosion of an uplifted part of the Czorsztyn sedimentary area. During the Cenomanian and Turonian the post-volcanic thermal subsidence caused a gradual deepening of the Magura Basin which resulted in the Turonian deepening of the Magura Basin beneath the local CCD. The Neo-Cimmerian extensional tectonics were accompanied by local intra-plate volcanism (Krobicki et al., 2008; Birkenmajer and Lorenz, 2008; Spišiak et al., 2011). According to Birkenmajer and Lorenc (2008) the basaltic olistolith from Biała Woda is evidence of alkaline volcanism connected with tensional faulting enabling mantle magma to intrude to the surface. These authors suggest that the volcanic events terminated due to subduction processes initiated during the Aptian-Albian at the southern borders of the Pieniny Klippen Belt Basin.

It is characteristic that the manifestations of volcanism in the PKB are marked at the western and eastern terminations of the belt: Western Carpathian Transfer Zone (WCTZ, see Picha et al., 2006) or Vienna Transform Fault and Maramuresh Transform Fault. At the beginning of the Campanian the southern part of the Magura Basin, under the influence of compression in the Pieniny Klippen Belt, had been shallowing (Fig. 15). Further shallowing of the basin and uplift and erosion of the $\mathrm{PKB}$ resulted in deposition of conglomerates and conglomer- atic sandstones of the Jarmuta Formation (Maastrichtian to Paleocene, see Birkenmajer, 1977). The coarse material and rock blocks (olistoliths) were derived mainly from the erosion of the PKB and the exotic Andrusov Ridge (Krobicki and Olszewska, 2005). The basaltic block of Biała Woda was incorporated into the clastic material together with carbonate clasts (Fig. 15). The present-day tectonic position of the volcanic rocks described is a consequence of the Eocene escape of the Alcapa microplate against the Tisza microplate and the Miocene rotation of these microplates (Ustaszewski et al., 2008; Oszczypko and Oszczypko-Clowes, 2009).

\section{CONCLUSIONS}

The Velykyi Kamenets' basalt, tuffs from Velykyi Kamenets' and Vilkhivchyk as well as the Biała Woda basaltic olistolith represent the same tectonomagmatic type of volcanism. This intrusive-effusive sequence probably developed during one Early Cretaceous volcanic phase, which took place in submarine conditions. The time of the volcanic event can be approximately estimated as not older than Berriasian and not younger than Albian. The period of volcanic activity in the PKB in Ukraine (Velykyi Kamenets') and Poland (Biała Woda) was roughly the same, a little older than that which took place in the Vah valley (Slovakia).

The rocks studied are featured by geochemical factors typical of ocean island alkali basalts of intraplate character without crustal contamination. Their parent magma probably derived 


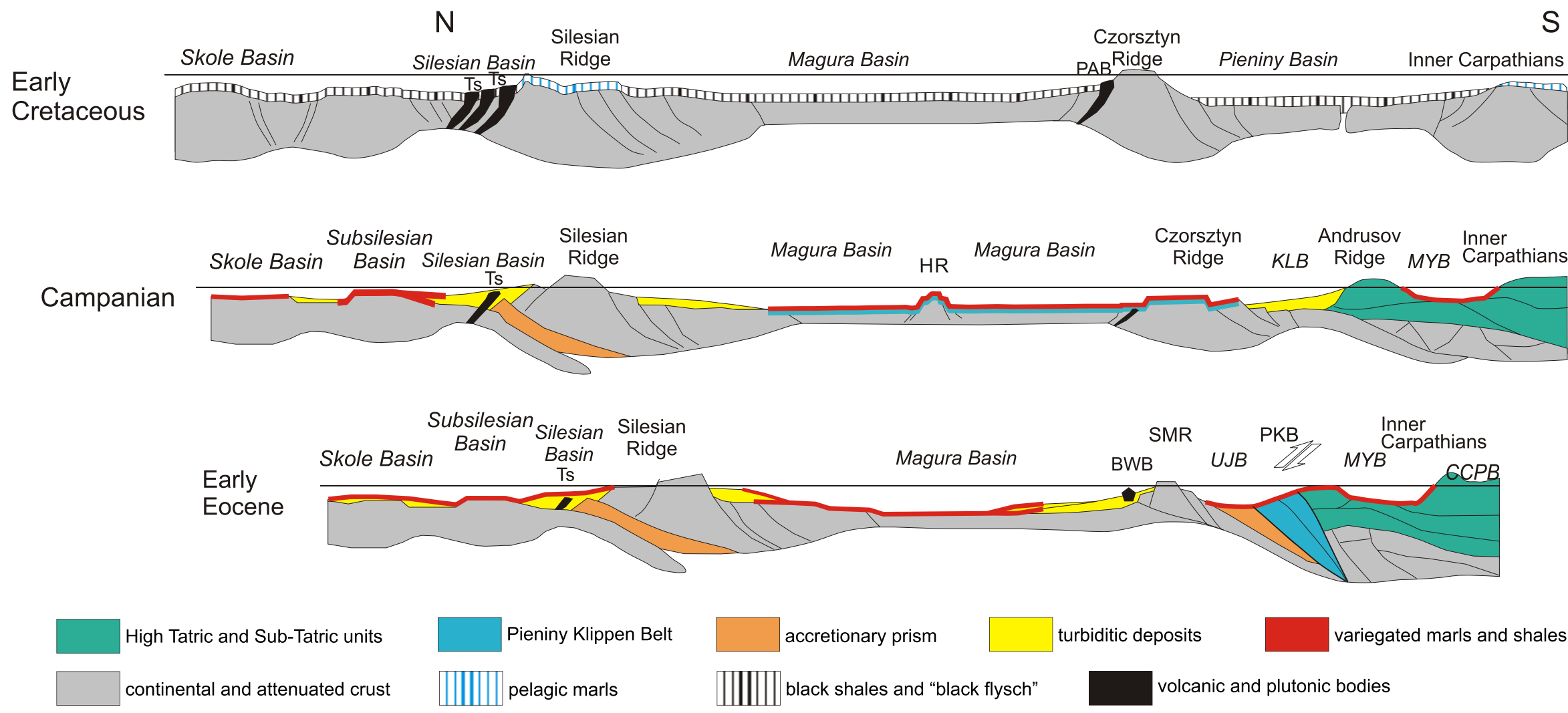

Fig. 15. Early Cretaceous-Early Eocene palinspastic evolutionary model for the Magura Basin, not to scale (based on Oszczypko, 2006, modified)

CCPB - Central Carpathian Paleogene Basin, HR - Hluk Ridge, UJB - Ujak Basin, KLB - Klapa Basin, MYB - Myjava Basin, PKB - Pieniny Klippen Belt, SMR - South Magura Ridge, Ts - teschenites, PAB - Pieniny alkaline basalts, BWB - Biała Woda basaltic block 
from a HIMU reservoir type. In terms of mineral composition and geochemistry, the rocks studied correspond well to other Cretaceous volcanic rocks reported from the Central and Outer Western Carpathians. The rocks studied, occurring in the western Ukraine, most probably belong to the Cretaceous Carpathian alkaline province. The volcanic processes seem to have been connected with deep tensional faults developed in marginal parts of the peripheral basins surrounding the Penninic spreading centres.
Acknowledgments. The investigations were financially supported by the grant no PB 0446/P04/2005, the Jagiellonian University (DS and BW funds) and AGH grant 11.11.140.173. We thank Prof. C. Breitkreuz and an anonymous reviewer for the constructive remarks. Our thanks go also to our colleagues from the Jagiellonian University: Dr. E. Koszowska for careful reading and suggestions for improving the manuscript and to Dr. M. Skiba for help in interpretation of clay mineral data.

\section{REFERENCES}

ALLÈGRE C.J., SCHIANO P. and LEWIN E. (1995) - Differences between oceanic basalts by multitrace element ratio topology. Earth Planet. Sc. Lett., 129: 1-12.

ANDRUSOV D. (1945) - Geological investigations of the inner Klippen Belt in the Western Carpathians (in Slovak). Part IV - Stratigraphy of Dogger and Malm, Part V - Stratigraphy of the Cretaceous. Práce Štátn. Geol. úst., 13.

AROLDI C. (2001) - The Pienides in Maramuresh-sedimentation, tectonics and paleogeography. Cluj University Press.

BIRKENMAJER K. (1958) - New contributions to the geology of magmatic rocks of the Szczawnica area (in Polish with English summary). Pr. Muz. Ziemi, 1: 89-103.

BIRKENMAJER K. (1977) - Jurassic and Cretaceous lithostratigraphic units of the Pieniny Klippen Belt, Carpathians, Poland (in Polish with English summary). Studia Geol. Pol., 45.

BIRKENMAJER K. (1979) - Przewodnik geologiczny po pienińskim pasie skałkowym. Wyd. Geol., Warszawa.

BIRKENMAJER K. (1986) - Stages of structural evolution of the Pieniny Klippen Belt, Carpathians. Studia Geol. Pol., 88: 7-32.

BIRKENMAJER K. (1988) - Exotic Andrusov Ridge: its role in plate tectonic evolution of the West Carpathian Foldbelt. Studia Geol. Pol., 91: 7-37.

BIRKENMAJER K. and LORENC M.W. (2008) - Lower Cretaceous exotic intraplate basaltoid olistolith from Biała Woda, Pieniny Klippen Belt, Poland: geochemistry and provenance. Studia Geol. Pol., 131: 237-246.

BIRKENMAJER K. and PÉCSKAY Z. (2000) - Early Cretaceous K-Ar age of a large basalt olistolith at Biała Woda, Pieniny Klippen Belt, West Carpathians, Poland. Studia Geol. Pol., 117: 27-35.

BIRKENMAJER K. and WIESER T. (1990) - Exotic rock fragments from Upper Cretaceous deposits near Jaworki, Pieniny Klippen Belt, West Carpathians, Poland (in Polish with English summary). Studia Geol. Pol., 97: 7-67.

BOMBIŢĂ G. and POP G. (1991) - Mesozoic formations from Poiana Botizei, Pieniny Klippen Belt of Romania. Geol. Carpath., 42: 139-146.

BOMBIŢĂ G. and SAVU H. (1986) - Sur les roches volcaniques associées aux klippes piénines de Poiana Botizei (Maramures roumain). Ann. Soc. Geol. Pol., 56: 337-348.

BOMBIŢĂ G., ANTONESCU E., MALATA E. and ION J. (1992) Pieniny-type Mesozoic formations from Maramures, Romania (second part). Acta Geol. Hung., 35: 117-144.

BÜCHL A. and GIER S. (2003) - Petrogenesis and alteration of tuffs associated with continental flood basalts from Putorana, northern Siberia. Geol. Mag., 140: 649-659.

CHRISTIDIS G.E. (1998) - Comparative study of the mobility of major and trace elements during alteration of and andesite and a rhyolite to bentonite, in the islands of Milos and Kimolos, Aegean, Greece. Clays Clay Miner., 46: 379-399.

COOK C., BRIGGS R.M., SMITH I.E.M. and MAAS R. (2005) - Petrology and geochemistry of intraplate basalts in the South Auckland vol- canic field, New Zealand: evidence for two coeval magma suites from distinct sources. J. Petrol., 46: 473-503.

DECKER K. (1990) - Plate tectonics and pelagic facies: Late Jurassic to Early Cretaceous deep-sea sediments of the Ybbsitz ophiolite unit (Eastern Alps, Austria). Sedim. Geol., 67: 85-99.

DEER W.A., HOWIE R.A. and ZUSSMAN J. (1992) - An introduction to the rock-forming minerals. New York, John Wiley.

DOSTAL J. and OWEN J.V. (1998) - Cretaceous alkaline lamprophyres from north eastern Czech Republic: geochemistry and petrogenesis. Geol. Rd., 87: 67-77.

FREY F.A., GREEN D.H. and ROY S.D. (1978) - Integrated models of basalt petrogenesis: a study from quartz tholeiites to olivine menilites from southeastern Australia utilizing geochemical and experimental petrologic data. J. Petrol., 19: 463-513.

GOLONKA J., OSZCZYPKO N. and ŚLACZKA A. (2000) - Late Carboniferous-Neogene geodynamic evolution and paleogeography of the circum-Carpathian region and adjacent areas. Ann. Soc. Geol. Pol., 70: $107-136$.

GOLONKA J., KROBICKI M., OSZCZYPKO N., ŚLĄCZKA A. and SŁOMKA T. (2003) - Geodynamic evolution and paleogeography of the Polish Carpathians and adjacent areas during Neo-Cimmerian and preceding events (latest Triassic-earliest Cretaceous). Geol. Soc. Spec. Publ., 208: 138-158.

GOLONKA J., KROBICKI M., OSZCZYPKO N., SŁABY E., SŁOMKA T., POPADYUK I. and NETCHEPURENKO A. (2004) - Mesozoic volcanism associated with triple-junction zone of the eastern Carpathians (Ukraine). Miner. Soc. Pol. - Spec. Pap., 22: 45-50.

HARANGI Sz., TONARINI S., VASELLI O. and MANETTI P. (2003) Geochemistry and petrogenesis of Early Cretaceous alkaline igneous rocks in Central Europe: implications for a long-lived EAR-type mantle component beneath Europe. Acta Geol. Hung., 46: 77-94.

HORWITZ L. and RABOWSKI F. (1929) - Excursion dans les Piénines (Karpates polonaises) de la Sociéte Géologique Polonaise (18-21 V 1929) (in Polish with French summary). Rocz. Pol. Tow. Geol., 6: 109-155.

HOVORKA D. and SPIŠIAK J. (1993) - Mesozoic volcanic activity of the Western Carpathian segment of the Tethyan Belt: diversities in space and time. Jb. Geol. B.-A., 136: 769-782.

HOVORKA D., DOSTAL J. and SPIŠIAK J. (1999) - Geochemistry of the Cretaceous alkali basaltic rock of the central part of the Western Carpathians (Slovakia). Krystalinikum, 25: 37-48.

IVAN P., HOVORKA D. and MÉRES S. (1999) - Riftogenic volcanism in the Western Carpathian geological history: a review. Geolines, 9: 41-47.

JACKSON M.L., ed. (1969) - Soil chemical analysis - advanced course: 2nd. Madison, Wis.

KAMIEŃSKI M. (1931) - Nouvelles contributions à la connaissance des roches éruptives de Piènines (in Polish with French summary). Rocz. Pol. Tow. Geol., 7: 217-233.

KROBICKI M. and OLSZEWSKA B. (2005) - Urgonian-type microfossils in exotic pebbles of the Late Cretaceous and Palaeogene 
gravelstones from the Sromowce and Jarmuta formations (Pieniny Klippen Belt, Polish Carpathians). Studia Geol. Pol., 124: 215-235.

KROBICKI M., KRUGLOV S.S., MATYJA B.A., WIERZBOWSKI A., AUBRECHT R., BUBNIAK A. and BUBNIAK I. (2003) - Relation between Jurassic klippen successions in the Polish and Ukrainian parts of the Pieniny Klippen Belt. Miner. Slov., 35: 56-58.

KROBICKI M., BUDZYŃ B., GOLONKA J., KRUGLOV S., MALATA E., MICHALIK M., OSZCZYPKO N., SKIBA M., SŁABY E., SŁOMKA T. and ZYCH B. (2005) - Petrography and mineralogy of the Late Jurassic-Early Cretaceous volcanic rocks in the Ukrainian part of the Carpathians. Miner. Soc. Pol. - Spec. Pap., 25: 323-328.

KROBICKI M., OSZCZYPKO N., SALATA D. and GOLONKA J. (2008) - Intra-plate alkaline volcanism in the Pieniny Klippen Belt (Eastern Carpathians, Ukraine). In: Proc. and Excursion Guide of the 6th Meeting of the Central European Studies Group (CETEG) (eds. Z. Nemeth and D. Plašienka): 73-74. State Geological Institute of Dionýz Štur, Bratislava.

KUDĚLÁSKOVÁ J. (1982) - Petrology and geochemistry of selected rock types of teschenite association, outer Western Carpathians. Geol. Carpath., 38: 545-573.

LANGMUIR C.H., BENDER J.F., BENCE A.E., HANSON G.N. and TAYLOR S.R. (1977) - Petrogenesis of basalts from the FAMOUS area: Mid-Atlantic Ridge. Earth Planet. Sc. Lett., 36: 133-156.

LASHKEVITSCH Z.M., MEDVEDEV A.P. and KRUPSKIY Y.Z. (1995) - Tektonomagmatitcheskaya evolutsya Karpat. Naukova Dumka.

LEWANDOWSKI M., KROBICKI M., MATYJA B.A. and WIERZBOWSKI A. (2005) - Palaeogeographic evolution of the Pieniny Klippen Basin using stratigraphic and palaeomagnetic data from the Velykyi Kamenets section (Carpathians, Ukraine). Palaeogeogr. Palaeoclimatol. Palaeoecol., 216: 53-72.

LOMIZE M.G. (1968) - Pozdneyourskoi vulkanizm Vostochnych Karpat. Vestn. Mosk. Univ., Ser. Geol., 6: 42-58.

MAHMOOD A. (1973) - Petrology of the teschenitic rock series from the type area of Cieszyn (Teschen) in the Polish Carpathians. Rocz. Pol. Tow. Geol., 43 (2): 153-212.

MALPAS J., DUZGOREN-AYDIN N.S. and AYDIN A. (2001) - Behaviour of chemical elements during weathering of pyroclastic rocks, Hong Kong. Environment. Inter., 26: 359-368.

McDONOUGH W. and SUN S. (1995) - The composition of the Earth. Chem. Geol., 120: 223-253.

MESCHEDE M. (1986) - A method of discriminance between different types of mid-ocean ridge basalts and continental tholeiites with the Nb-Zr-Y diagram. Chem. Geol., 56: 207-218.

MIKUŠ T., SPIŠIAK J., SÝKORA M. and DEMKO R. (2006) - Chemical composition of spinels from Mesozoic alkali basalts of the Western Carpathians - implications for sources of detrital spinels in flysch sediments. Geol. Carpath., 57: 447-460.

MOORE D.M. and REYNOLDS R.C. (1997) - X-ray diffraction and the identification and analysis of clay minerals. 2nd edition. Oxford University Press.

MORIMOTO N., FABRIES J., FERGUSON A.K., GINZBURG I.V., ROSS M., SEIFERT F.A., ZUSSMAN J., AOKI K. and GOTTARDI G. (1988) - Nomenclature of pyroxenes. Am. Miner., 73: 1123-1133.

NAREBBSKI W. (1990) - Early rift stage in the evolution of western part of the Carpathians: geochemical evidence from limburgite and teschenite rock series. Geol. Carpath., 41: 521-528.

OSZCZYPKO N. (1992) - Late Cretaceous through Paleogene evolution of Magura Basin. Geol. Carpath., 43: 333-338.

OSZCZYPKO N. (1999) - From remnant oceanic basin to collision-related foreland basin - a tentative history of the Outer Carpathians. Geol. Carpath. 50, spec. issue: 161-163.

OSZCZYPKO N. (2004) - The structural position and tectonosedimentary evolution of the Polish Outer Carpathians. Prz. Geol., 52 (8/2) 780-791

OSZCZYPKO N. (2006) - Late Jurassic-Miocene evolution of the Outer Carpathian fold-and thrust belt and its foredeep basin (Western Carpathians, Poland). Geol. Quart., 50 (1): 169-194.

OSZCZYPKO N. and OSZCZYPKO-CLOWES M. (2009) - Stages in the Magura Basin: a case study of the Polish sector (Western Carpathians). Geodinam. Acta, 22 (1-3): 83-100.
OSZCZYPKO N., OSZCZYPKO-CLOWES M., GOLONKA J. and KROBICKI M. (2005) - Position of the Marmarosh Flysch (Eastern Carpathians) and its relation to the Magura Nappe (Western Carpathians). Acta Geol. Hung., 48: 259-282.

OSZCZYPKO N., OLSZEWSKA B. and MALATA E. (2012) - Cretaceous (Aptian/Albian-?Cenomanian) age of "black flysch" and adjacent deposits of the Grajcarek thrust sheets in the Małe Pieniny Mts. (Pieniny Klippen Belt, Polish Outer Carpathians). Geol. Quart., 56 (3): 411-439.

OYARZUN R., DOBLAS M., LÓPEZ-RUIZ J. and CEBRÁ J.M. (1997) Opening of the central Atlantic and asymmetric mantle upwelling phenomena: implications for long-lived magmatism in western North Africa and Europe. Geology, 25: 727-730.

PICHA F., STRANIK Z. and KREJCI O. (2006) - Geology and hydrocarbon resources of the Outer Western Carpathians and their foreland, Czech Republik. AAPG Mem., 84: 49-176.

PLAŠIENKA D. (2003) - Dynamics of Mesozoic pre-orogenic rifting in the Western Carpathians. Mitt. Österr. Geol. Ges., 94 (2001): 79-98.

PRICE R.C., GRAY C.M., WILSON E.M., FREY F.A. and TAYLOR S.R. (1991) - The effects of weathering on rare-earth element, Y and Ba abundances in Tertiary basalts from southeastern Australia. Chem. Geol., 93: 245-265.

REHÁKOVÁ D., MATYJA B., WIERZBOWSKI A., SCHLÖGL J., KROBICKI M. and BARSKI M. (2011) - Stratigraphy and microfacies of the Jurassic and lowermost Cretaceous of the Velyki Kamenets section (Pieniny Klippen Belt, Carpathians, Ukraine). Vol. Jurassica, 9 (9): 61-104.

ROGOZIŃSKI B. and KROBICKI M. (2006) - The geology of the eastern slopes of Mt Pietros in the Chornohora Range (The Ukrainian Carpathian Mountains) (in Polish with English summary). In: Czarnohora - Przyroda i Człowiek (ed. M. Troll): 17-26. Inst. Geogr. Gospod. Przestrz. Uniw. Jagiellońskiego, Kraków.

ROLLINSON H.R. (1993) - Using geochemical data: evaluation, presentation, interpretation. Longman Scientific and Technical: 102-133.

SCHMID S.M., FÜGENSCHUH B., KISSLING E. and SCHUSTER R. (2004) - Tectonic map and overall architecture of the Alpine orogen. Ecl. Geol. Helv., 97: 93-117.

SCHMID S.M., BERNOULLI D., FÜGENSCHUH B., MATENCO L., SCHUSTER R., SCHEFEE S., TISCHLER M. and USTASZEWSKI K. (2008) - The Alpine-Carpathian-Dinaridic orogenic system: correlation and evolution of tectonic units. Swiss J. Geosc., 101: 139-183.

SCHNABEL W. (1992) - New data on the Flysch Zone of the Eastern Alps in the Austrian sector and new aspects concerning the transition to the Flysch Zone of the Carpathians. Cret. Res., 13: 405-419.

SPIŠIAK J. and SÝKORA D. (2009) - Geochemistry and mineralogy of the Hanigovce basalts the Proč (Jarmuta) beds. In: Geochemia 2009 (eds. L. Jurkovič, I. Slaninka and O. Durža): 106-109. Konf., Symp. State Geological Institute of Dionýz Štur, Bratislava..

SPIŠIAK J., BUČOVA J., PLAŠIENKA D. and MIKUŠ T. (2008) - Cretaceous alkali volcanites in the Chmielova region (Vršatec Klippen area, Pieniny Klippen Belt, Western Carpathians). In: Proceedings and Excursion Guide of the 6th Meeting of the Central European Studies Group (CETEG) (eds. Z. Nemeth and D. Plašienka): 124-125. State Geological Institute of Dionýz Štur, Bratislava.

SPIŠIAK J., PLAŠIENKA D., BUČOVÁ J., MIKUŠ T. and UHER P. (2011) - Petrology and palaeotectonic setting of Cretaceous alkaline basaltic volcanism in the Pieniny Klippen Belt (Western Carpathians, Slovakia). Geol. Quart., 55 (1): 27-48.

SUMMA L.L. and VEROSUB K.L. (1992) - Trace element mobility during early diagenesis of volcanic ash: applications to stratigraphic correlation. Quat. Internat., 13/14: 149-57.

SUN S.S. and McDONOUGH W.F. (1989) - Chemical and isotopic systematics of oceanic basalts: implications for mantle compositions and processes. Geol. Soc. Spec. Publ., 42: 313-345.

ŚLĄCZKA A., KRUGLOV S., GOLONKA J., OSZCZYPKO N. and POPADYUK I. (2006) - Geology and hydrocarbon resources of the Outer Carpathians, Poland, Slovakia, and Ukraine: general geology. AAPG Mem., 84: 212-258.

THOMPSON R.N. (1982) - British Tertiary volcanic province. Scott. J. Geol., 18: 49-107. 
USTASZEWSKI K., SCHMID S.M., FÜGENSCHUH B., TISCHLER M., KISSLING E. and SPAKMAN W. (2008) - A map-view restoration of the Alpine-Carpathian-Dinaridic system for the Early Miocene. Swiss J. Geosc., 101 Suppl., 1: 273-294.

Van der WEIJDEN C.H. and van der WEIJDEN R.D. (1995) - Mobility of major, minor and some redox-sensitive trace elements and rare-earth elements during weathering of four granitoids in central Portugal. Chem. Geol., 125: 149-167.

VARITCHEV A. (1997) - Major and trace element geochemistry of Mesozoic igneous formation of the Ukrainian Carpathians as an indicator of paleotectonic settings. Prz. Geol., 45 (10): 1109-1110.

WEAVER B.L. (1991) - The origin of ocean island end-member compositions: trace element and isotopic constraints. Earth Planet. Sc. Lett., 104: 381-397.

WEDEPOHL K.H. (1969) - Handbook of Geochemistry. Springer Verlag, Berlin.

WILSON M. (1993) - Magmatism and the geodynamics of basin formation. Sedim. Geol., 86: 5-29.
WILSON M. (1997) - Thermal evolution of the Central Atlantic passive margin: continental breakup above a Mesozoic superplume. J. Geol. Soc., 154: 491-495.

WINCHESTER J.A. and FLOYD P.A. (1977a) - Geochemical magma type discrimination; application to altered and metamorphosed basic igneous rocks. Earth Planet. Sc. Lett., 20: 325-343.

WINCHESTER J. and FLOYD P. (1977b) - Geochemical discrimination of different magma series and differentiation products using immobile elements. Chem. Geol., 20: 325-43.

WOOD D.A. (1980) - The application of a Th-Hf-Ta diagram to problems of tectonomagmatic classification and to establishing the nature of crustal contamination of basaltic lavas of the British Tertiary volcanic province. Earth Planet. Sc. Lett., 50: 11-30.

ZIELINSKI R.A. (1982) - The mobility of uranium and other elements during alteration of rhyolite ash to montmorillonite: a case study in the Troublesome Formation, Colorado, USA. Chem. Geol., 35: 185-204. 